\title{
Monetary Policy, Private Debt and Financial Stability Risks
}

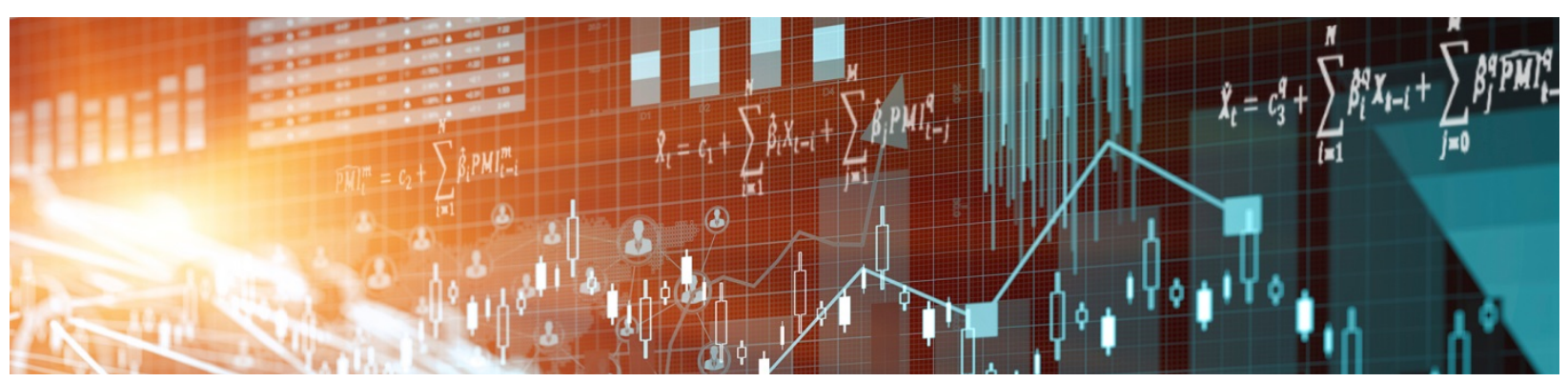

by Gregory H. Bauer and Eleonora Granziera 
Bank of Canada Staff Working Paper 2016-59

December 2016

\title{
Monetary Policy, Private Debt and Financial Stability Risks
}

\author{
by \\ Gregory H. Bauer ${ }^{1}$ and Eleonora Granziera ${ }^{2}$ \\ 1Financial Markets Department \\ Bank of Canada \\ Ottawa, Ontario, Canada K1A 0 G9 \\ gbauer@bankofcanada.ca \\ Bank of Finland \\ Snellmaninaukio Helsinki, Finland \\ eleonora.granziera@gmail.com
}




\section{Acknowledgements}

We would like to thank Oscar Jorda, Jim Hamilton, Alexander Ueberfeldt and seminar participants at the 2016 IJCB Annual Research Conference, Bank of Finland, Bank of Italy, Bank of Spain, Bundesbank, European Central Bank, and Universitat Pompeu Fabra for helpful comments. Graeme Westwood provided outstanding research assistance. The views expressed in this paper are those of the authors. No responsibility for them should be attributed to the Bank of Canada or the Bank of Finland. 


\begin{abstract}
Can monetary policy be used to promote financial stability? We answer this question by estimating the impact of a monetary policy shock on private-sector leverage and the likelihood of a financial crisis. Impulse responses obtained from a panel VAR model of 18 advanced countries suggest that the debt-to-GDP ratio rises in the short run following an unexpected tightening in monetary policy. As a consequence, the likelihood of a financial crisis increases, as estimated from a panel logit regression. However, in the long run, output recovers and higher borrowing costs discourage new lending, leading to a deleveraging of the private sector. A lower debt-to-GDP ratio in turn reduces the likelihood of a financial crisis. These results suggest that monetary policy can achieve a less risky financial system in the long run but could fuel financial instability in the short run. We also find that the ultimate effects of a monetary policy tightening on the probability of a financial crisis depend on the leverage of the private sector: the higher the initial value of the debt-to-GDP ratio, the more beneficial the monetary policy intervention in the long run, but the more destabilizing in the short run.
\end{abstract}

Bank topics: Monetary policy; Financial stability; Credit and credit aggregates; Transmission of monetary policy

JEL codes: E; E52; E58; C21; C23

\title{
Résumé
}

La politique monétaire peut-elle aider à soutenir la stabilité financière? Pour répondre à cette question, nous estimons l'incidence qu'un choc de politique monétaire aurait sur le levier financier du secteur privé et sur la probabilité de voir survenir une crise financière. Les fonctions de réaction tirées du modèle vectoriel autorégressif sur données de panel utilisé pour 18 pays avancés tendent à montrer que le ratio de la dette au PIB augmente à court terme après un resserrement inattendu de la politique monétaire. L'éclatement d'une crise financière devient alors plus probable, comme l'indiquent les estimations du modèle de régression logit. Sur le long terme en revanche, la production se redresse, et la hausse du coût du crédit décourage de nouveaux emprunts, ce qui aboutit à une diminution du levier financier dans le secteur privé. La baisse du ratio de la dette au PIB rend l'éclatement d'une crise financière moins probable. Ces résultats semblent montrer que la politique monétaire permet de réduire les risques pour la stabilité du système financier sur le long terme, mais qu'elle crée davantage d’instabilité dans le système financier à court terme. Il apparaît également que les effets finaux d’un resserrement de la 
politique monétaire sur la probabilité d'une crise dépendent du niveau du levier financier du secteur privé : plus le ratio de la dette au PIB est élevé au départ, plus la politique monétaire apportera de bénéfices à long terme, mais plus elle créera d'instabilité à court terme.

Sujets : Politique monétaire; Stabilité financière; Crédit et agrégats du crédit; Transmission de la politique monétaire

Codes JEL : E; E52; E58; C21; C23 


\section{Introduction}

In the wake of the recent financial crisis, policy-makers have disagreed about whether central banks should extend their inflation targeting mandates to promote financial stability. The supporters of "leaning against the wind" policies argue that low-for-long policy rates may help contribute to the build-up of debt that ultimately poses a risk to financial stability. This is particularly true in the housing market, where low rates may encourage households to take on larger mortgages and spur house price overvaluation (Taylor 2007, 2010). Because of these concerns, some have argued that monetary authorities should raise interest rates more than is warranted by contemporaneous price and output stability objectives alone (Borio 2014).

As monetary policy has a wide impact on both the economy and financial markets, setting interest rates higher than suggested by the central bank monetary policy rule might be costly in terms of lower inflation and lower output. For this reason, other policy-makers believe that financial stability should be achieved separately through targeted financial regulation and supervision (e.g., Svensson 2014). Monetary policy should then be used at most to "clean"; i.e., policy should stabilize output and inflation after the bust in asset prices has occurred (Mishkin 2011, Greenspan 2002).

There is a middle ground: even if monetary policy is viewed as the last line of defence, there might be a case for monetary policy intervention to address financial stability concerns when large financial imbalances affect the short-term outlook for output and inflation. Moreover, when a low interest rate environment has encouraged the build-up of broadly based as opposed to sector-specific imbalances, monetary policy might complement macroprudential policy and directly contribute to financial stability. ${ }^{1}$ However, this view relies on the efficacy of leaning when imbalances are higher than normal.

In all of these cases, the rationale for central bank intervention rests on the assumptions that monetary policy is able to reverse the build-up of excess leverage and that "leaning against the wind" policies can be beneficial. However, the effect of monetary policy interventions on key risk indicators - such as the debt-to-GDP ratio-is a priori ambiguous: on the one hand, contractionary policies might lower both debt and the probability of a future crisis over the medium run, while on the other hand, they might have a negative impact on inflation and real activity in the short run. Thus, there are a number of outstanding questions facing policy-makers. How effective is monetary policy in lowering the leverage

\footnotetext{
${ }^{1}$ See Smets (2014) for a detailed summary of the views on the role of monetary policy and macroprudential policies in promoting the soundness of the financial system.
} 
of the private sector along with the subsequent likelihood of a financial crisis? Does this happen over the short or long run? Is leaning better undertaken when financial imbalances are low, or should it occur only when the likelihood of a crisis has become more apparent?

In this paper we contribute to the debate on the leaning versus cleaning roles of monetary policy by investigating whether monetary policy can achieve less leveraged and ultimately less risky economies. We structure our analysis in two steps. In the first step, we assess whether monetary policy can successfully decrease the leverage of the private sector, measured via the private debt-to-GDP ratio. As individual countries have experienced only a small number of financial cycles and financial crises during the last 40 years, it would be difficult to determine the impact of a monetary policy shock on financial stability using data from a single country alone. For this reason we consider a broad cross-section of countries that have experienced financial cycles and crises of varying amplitude, size and timing. In particular, we construct a comprehensive data set for 18 advanced economies from 1975Q1 to 2014Q4. The data include measures of real economic activity, prices, credit and financial variables. We obtain an aggregate impulse response function of the private debt-to-GDP ratio to a monetary policy shock by averaging impulse responses estimated from individual country VARs. In contrast to most of the existing studies, we use sign restrictions to identify a contractionary structural monetary policy shock while remaining agnostic about the response of the private debt-to-GDP ratio.

In the second step, we relate the private-sector leverage to the likelihood of a financial crisis occurring in the future by using a cross-country panel logit regression. Conditional on the response of the variables to the monetary policy shock and on the panel logit estimates, we can then evaluate the effects of the unanticipated tightening on the subsequent likelihood of a crisis. Some recent studies have analyzed the effect of monetary policy shocks on private debt, while others have focused on the determinants of financial crises. To the best of our knowledge, this is the first empirical paper that studies the effects of monetary policy on private debt and its repercussions for the likelihood of financial crises in a unified framework.

Our results provide new evidence on the questions posed above. A sizable, contractionary monetary policy shock causes real private debt (in deviation from trend) to rise on impact, as nominal debt barely responds and inflation falls. As output shrinks, the debt-to-GDP ratio increases in the short run. In the medium to long run, output recovers and debt decreases, ultimately resulting in a decline in the debt-to-GDP ratio. However, as the probability of a financial crisis increases with the debt-to-GDP ratio, we find that initially a crisis becomes more likely. A contractionary policy is thus risky in the short run. Eventually, 
as the cumulative response of the debt-to-GDP ratio turns negative, the probability of a crisis drops to a lower value than it was before the shock. Our analysis thus suggests the existence of an intertemporal trade-off that is new to the literature: while an unexpected monetary policy tightening might reduce leverage and promote financial stability in the long run, it might actually generate financial fragility in the short run. The economy may have to experience short-term pain to achieve long-term gain.

A further novel result is that the effectiveness of monetary policy in mitigating the probability of a financial crisis depends on the current leverage of the economy. In general, an unexpected tightening will ultimately be more effective the higher the initial debt-to-GDP ratio with respect to trend, but in the short term, it will be more destabilizing. Waiting until financial imbalances are quite high before increasing policy rates can be risky. This result helps policy-makers evaluate the trade-off between starting to lean sooner rather than later.

Our paper is related to two growing strands of the literature that discuss the role of monetary policy and financial stability. The first strand examines the role of monetary policy and private debt. From a theoretical perspective, Alpanda and Zubairy (2014) and Gelain, Lansing and Natvik (2015) use a dynamic stochastic general equilibrium (DSGE) model to find that an unexpected tightening of policy rates affects real private debt through the housing sector by increasing mortgage rates and discouraging new lending. However, it also directly affects the non-housing sectors of the economy. In these models, only new loans respond to a monetary policy shock. As these loans represent a small fraction of total debt, the response of real debt is negative but moderate, implying an increase in the debt-to-GDP ratio in the short run. Svensson (2013) reaches the same conclusion using a partial equilibrium model of household debt dynamics calibrated to the Swedish economy. We include a national house price index in our model to help account for the importance of mortgage market dynamics. Our findings confirm empirically the results in these structural studies using a broad cross-section of country experience.

The existing empirical evidence on the effect of monetary policy on private debt is limited and focuses mostly on single-country estimates (e.g., Angeloni et al. (2015) for the United States, Laséen and Strid (2013) for Sweden, and Robstad (2014) for Norway). Goodhart and Hofmann (2008) argue that estimates from individual countries might be imprecise and they conduct a panel VAR analysis of house prices, money and credit for a sample of industrialized economies. In all of these studies, real debt decreases after a contractionary monetary policy shock, but there is no consensus about the response of the debt-to-GDP ratio. Most of these studies use short-run zero restrictions to identify a monetary policy shock and constrain debt 
so as not to respond to a monetary policy shock on impact.

There is a growing interest in evaluating the role of private-sector leverage as a potential source of financial instability. Gourinchas and Obstfeld (2012), Babecký et al. (2012), Schularik and Taylor (2012) and Aikman et al. (2015) show that private domestic credit expansion is a significant predictor of financial crises. However, these papers do not investigate how monetary policy can affect credit. To the best of our knowledge, we provide the first empirical assessment of how monetary policy shocks translate into changes in leverage that affect the likelihood of a financial crisis.

Finally, a small number of recent papers use structural models to weigh the benefits and costs of "leaning against the wind" policies. Ajello et al. (2016) and Alpanda and Ueberfeldt (2016) introduce DSGE models for the United States and Canada, respectively, where the economy faces an endogenous probability of a financial crisis that is a function of private credit conditions. Svensson (2016) constructs an analytic model-calibrated to the Schularik and Taylor (2012) likelihood of a crisis - to show that leaning can be expensive as it implies that when a crisis commences, the economy is already bearing a higher level of unemployment. Gerdrup et al. (2016) construct a New Keynesian model in which the likelihood of the economy entering a financial crisis follows a Markov switching process that depends on credit growth. Leaning is also found to be expensive as it generates more volatile output and inflation in non-crisis periods. These calibrated studies have highlighted an intertemporal trade-off faced by monetary authorities: stabilization of output and inflation in normal times versus decreasing the probability and costs of a future financial crisis. We show new dynamics for the risk of contractionary policies and detail whether these policies should be taken earlier or later in the cycle.

In interpreting our results, we stress that we are not conducting a welfare analysis to weigh the benefits and costs of monetary policy tightening. In addition, we do not provide a metric to weigh short-term losses against long-term gains. Furthermore, our identified monetary policy shock is not directly interpretable as a systematic "leaning against the wind" policy. These considerations can be addressed in the context of general equilibrium models such as in Ajello et al. (2015) and Alpanda and Ueberfeldt (2016). Therefore, we provide an answer to the question of whether monetary policy could, rather than should, be used to promote financial stability.

The paper is organized as follows: Section 2 provides some stylized facts regarding the evolution of private debt and the occurrence of financial crises. Section 3 describes the panel VAR model and shows the impulse responses to a monetary policy shock. Section 4 reports 
the effects of leverage dynamics on the probability of a crisis and evaluates the impact of an unanticipated monetary policy tightening on the likelihood of a crisis. Section 5 concludes.

\section{Private Debt and Financial Crises: Stylized Facts from Cross-Country Evidence}

In this paper, we consider private-sector leverage as an indicator of financial stability and show that it acts as an important channel through which monetary policy can affect the probability of a financial crisis. We start by detailing the data on debt and then turn to our definitions of financial crises.

\subsection{Private debt}

We focus on leverage, as excessively leveraged economies might be less resilient to shocks and have lower loss-absorption capacities. Private-sector leverage is measured as the ratio of nominal private debt to nominal output. Private debt is defined as total credit provided by domestic banks to the domestic, private, non-financial sector. ${ }^{2}$ We base our analysis on private credit provided by banks as Jorda et al. (2015b) stress that bank credit is the predominant form of private-sector borrowing in advanced economies. The data for all countries in our analysis are collected by the Bank for International Settlements (BIS) and cover the sample $1975 \mathrm{Q} 1$ to $2014 \mathrm{Q} 4 .^{3}$

Figure 1 shows the weighted average of the debt-to-income ratio across countries where weights are given by countries' shares of output. ${ }^{4}$ In each quarter, the light grey area spans the range of values (minimum and maximum) across countries, while the dark shaded area delimits the 20th and 80th percentiles.

\footnotetext{
${ }^{2}$ The private non-financial sector includes non-financial corporations, households and non-profit institutions serving households. The series capture the outstanding amount of credit at the end of the reference quarter. Credit covers loans as well as debt securities.

${ }^{3}$ The countries included in our sample are Australia, Belgium, Canada, Denmark, Finland, France, Germany, Ireland, Italy, Japan, Netherlands, New Zealand, Norway, Spain, Sweden, Switzerland, the United Kingdom and the United States. We consider the longest sample for which credit is available for all countries.

${ }^{4}$ We compare our data on credit with the aggregate private bank credit to the private non-financial sector as percentage of GDP shown in Jorda et al. (2015b), available at the annual frequency from 1870. The series provided by Jorda et al. shows the same dynamics as the (unweighted) average of our series. The levels of both series are about 55 per cent in 1975 , and rise throughout the sample. They dip slightly to 80 per cent in 1995, reach a peak of almost 120 per cent in 2008-2009 and plummet in 2010.
} 
Private debt as a fraction of GDP has risen rapidly and substantially across countries, increasing from an average of about 55 per cent in 1975Q1 to 90 per cent in 2014Q4. The strong rise in leverage can be attributed primarily to a substantial increase in mortgage credit, which represented one-third of bank assets at the beginning of the 20th century and constitutes about two-thirds today (Jorda et al. 2015). At the same time, household borrowing was facilitated by higher levels of financial development (Chen et al. 2015). The level of the debt-to-GDP ratio shows a high degree of heterogeneity across countries that increased substantially during the financial crisis. The cross-sectional distribution of the debt-to-GDP ratio can be explained by different legal and economic institutions, including legal enforcement of contracts (e.g., the time needed to repossess a house (Bover et al. 2015)).

The upward trend in the debt-to-GDP ratio poses some challenges for empirical analysis. Moreover, the literature that studies the determinants of financial crises finds that the shortterm dynamics of credit or the deviations of debt-to-GDP from trend, rather than the level, are significant predictors of crises (e.g., Schularick and Taylor 2012, Gourinchas and Obstfeld 2012, Drehmann 2013, Babecký et al. 2012). We therefore use the debt-to-GDP gap, measured as deviation from a one-sided Hodrick-Prescott (HP) filter trend, in the analysis that follows. To account for the fact that credit cycles are characterized by longer duration and larger amplitude than those of traditional business cycles (Aikman et al. 2015, Aikman et al. 2016), we use a much larger smoothing parameter $(\lambda=400,000)$ than the one commonly used for quarterly data. The resulting trend is thus very slow-moving. This definition of the debt-to-GDP gap is also adopted under Basel III for the implementation of countercyclical capital buffers (Drehmann 2013).

While the trend is often ascribed to financial deepening, as financial innovations granted access to credit markets to previously unserved households and businesses, gaps in debt-toGDP ratio may reflect several causes. For example, credit expansions may be driven by active risk-taking of financial intermediaries due to incentives that may not be fully aligned with those of shareholders (e.g., Allen and Gale 2000 and Bebchuk, Cohen, and Spamann 2010). Alternatively, shareholder risk appetite may be elevated (Danielsson, Shin and Zigrand 2012 and Adrian, Moench and Shin 2013). Widespread optimism may be shared by financial intermediaries and other agents in the economy (Gennaioli, Shleifer and Vishny 2012, 2013; Reinhart and Rogoff 2009; Barberis 2012). In these environments, banks might have an incentive to underwrite poor-quality loans and seek risk, posing threats to financial stability. In the analysis that follows, we implicitly interpret large positive deviations from trend as reflecting expansions in "bad" credit due to the incentives just described. 
While there seems to be an upward trend in the ratio for all of the economies considered, the short-term dynamics of individual countries are quite heterogeneous. ${ }^{5}$ Figure 2 shows the number of countries in which the debt-to-GDP gap is higher or lower than 2 per cent in a given year. The figure suggests that while cyclical fluctuations might be correlated, they are not perfectly synchronized. ${ }^{6}$ For example, even during the recent financial crisis, when most countries experienced an increase in debt-to-GDP well above trend, some countries were deleveraging.

Moreover, looking at individual cross-country correlations, in some cases debt-to-GDP gaps are strongly positively correlated - e.g., Finland and Sweden (0.83), Australia and New Zealand (0.86) or Ireland and Spain (0.88) - while in others, the gaps are negatively correlated, as Japan and the Netherlands (-0.70) or Germany and Sweden (-0.79).

In our data, private-sector credit is strongly procyclical, as the average contemporaneous correlation between the growth rates of real output and real private debt is 50 per cent. This confirms a similar result in Jorda et al. (2015b).

The evolution of the housing market might be an important factor that can explain leveraging and deleveraging episodes. In fact, overvaluations in house prices might reflect high investor risk appetite and over-optimism, possible sources of large and rapid credit expansions. Indeed, in our sample, the contemporaneous correlation between debt-to-GDP ratio and real house prices ranges from 18 per cent in Germany to 65 per cent in the United States. Moreover, mortgage loans represent the majority of bank assets. Therefore, in the analysis that follows, we model the evolution of house prices and credit dynamics jointly.

\section{$2.2 \quad$ Financial crises}

In our analysis, we consider systemic banking crises that involve a large number of banks and therefore pose a threat to the entire economy. To identify the crises, we use the classification provided by Caprio and Klingebiel (2003) and Laeven and Valencia (2012). In data extending to 2003, Caprio and Klingebiel (2003) identify financial crises as periods of significant and system-wide financial distress in the banking system. In a longer data set, Laeven and Valencia (2012) impose an additional requirement that the distress must be followed by

\footnotetext{
${ }^{5}$ For example, while some countries, like Ireland, Spain and the United States have gone through a large leveraging-deleveraging episode during the recent financial crisis, others, like Canada, Switzerland and Sweden, are still experiencing an increase in borrowing relative to income.

${ }^{6}$ This finding is consistent with other studies; e.g., Baron and Xiong (2014).
} 
widespread insolvencies or significant banking policy interventions. ${ }^{7}$ In our application, we combine the two data sets. However, even after the two classifications have been combined, this definition of financial crises delivers only a small number of episodes in our sample. Moreover, the crises are difficult to date accurately, and most episodes coincide with the latest financial crisis of 2008-2011.

For these reasons, we consider an additional measure of financial stability risk: large bank equity corrections. Following Baron and Xiong (2016), we define a large bank equity correction as a decrease in the realized excess return on the national bank equity index of at least 25 per cent over one quarter, or of at least 35 per cent over two quarters. This definition identifies episodes of distress in the banking sector that might not lead to a fully fledged systemic banking crisis. However, they clearly show an impaired financial sector and likely translate into a reduction of the supply of financial services to the private sector. A monetary policy shock that reduces debt and leverage might decrease the likelihood of these tail episodes.

Table 1 shows the frequency, duration and losses associated with the different definitions of crises. We count 26 episodes of systemic banking crises occurring over the sample 1975Q12011Q4, of which 10 occur during 2007Q3-2011Q4. The stricter Laeven and Valencia (2012) classification identifies 18 crisis events; using this definition, most countries have experienced only one crisis, two have experienced two crises (Sweden and the United States) and three have never experienced any (Australia, Canada and New Zealand). Systemic banking crises are accompanied by large output losses with a cumulative decline in GDP in the first year of the crisis of 2.9 per cent for the Laeven and Valencia (2012) data and a decline of 1.2 per cent for the integrated data set. This compares with GDP growth rates of 2.6 (2.7) per cent per annum in non-crisis periods. Using the two combined data sets, the average duration of the crises is 19 quarters.

Large bank equity corrections are more frequent than systemic banking crises, with 88 occurrences of the former. However, they are shorter lived, lasting an average of only four quarters. They are also less severe disruptions to the financial system: while the excess rate of return on bank equity is -36.1 per cent during the first year of a correction, this is smaller than the 92.8 per cent and 66.3 per cent declines recorded during the two types of systematic crises. GDP grows by a scant 0.5 per cent during the first year of a bank equity correction compared with 2.6 per cent growth during all non-crisis periods. Thus, bank

\footnotetext{
${ }^{7}$ Significant banking policy interventions include, for example, extensive liquidity support, bank nationalization, asset purchase, deposit freezes or bank holidays.
} 
equity corrections are far more numerous but less costly.

Figure 3 shows the frequency of systemic banking crises and large bank equity corrections for each year in our sample. Large bank equity corrections are more evenly distributed than

systemic banking crises. In general, systemic banking crises are accompanied by large equity crashes, at least in the first year. We also observe episodes of large bank equity drops that were not followed by systemic banking crises, such as the crashes in the early 2000s, contemporaneous to the stock market downturn of 2002.

To provide additional insight, we conduct an event study analysis in which we show the dynamics of bank equity returns, debt-to-GDP gaps, output gaps and house prices gaps during an event window that runs from eight quarters before to eight quarters after a crisis episode. Figure 4 shows the average of variables around a systemic banking crisis (panel (a)), and a bank equity correction (panel (b)). The qualitative patterns of the variables are very similar across the two types of episodes. Bank equity returns fall with the beginning of the crisis, but the largest drop occurs after five quarters in the case of systemic banking crises. Returns are both lower and more volatile following the crisis. In the run-up to a crisis, debt-to-GDP gaps are positive and large, especially for systemic banking crises. While we observe some deleveraging right before the onset of the crisis, the speed of the adjustment in the debt-to-GDP ratio increases in the aftermath of the crisis. Both types of crises are associated with a significant decline in the output gap, which fails to close within the first two years. The recovery is more sluggish for systemic banking crises. As in the case of debt-to-GDP gaps, house prices are higher than trend before the crisis but they start to decline two to three quarters before the onset of both types of crises and continue to correct after that. While the dynamics are qualitatively similar across crises, the magnitude of the drops in output gaps, bank equity returns and house prices suggests that systemic banking crises are more costly than large bank equity corrections.

\section{Monetary Policy and Financial Cycles}

\subsection{VAR model}

We conduct a cross-country analysis that yields an estimated average response to a typical monetary policy shock across countries and across time of the debt-to-GDP ratio. Rather than estimating a panel VAR model that assumes countries are "similar enough" to pool their credit cycles, we estimate individual country VARs and pool the individual impulse 
responses. We thus do not impose dynamic homogeneity, which can deliver biased estimates of the autoregressive coefficients in dynamic panel models even when $T$ is large (Pesaran and Smith 1995). Dynamic heterogeneity might be induced by cross-country variation in the degree of financialization and other idiosyncratic characteristics that might affect the transmission mechanism of monetary policy.

The 18 country $i$ VARs each take the form:

$$
Y_{i, t}=A_{i}+\sum_{l=1}^{p} B_{i, l} Y_{i, t-l}+\varepsilon_{i, t} \quad i=1, . ., 18
$$

where $Y_{i, t}$ is a $K \times 1$ vector of endogenous variables, $A_{i}$ is a $K \times 1$ vector of country-specific intercepts, $B_{i, l}$ is a $K \times K$ matrix of autoregressive coefficients, and $\varepsilon_{i, t}$ is a $K \times 1$ vector of errors with $\varepsilon_{i, t} \sim N\left(0, \Sigma_{i}\right)$. The vector of endogenous variables includes real output, inflation, a short-term interest rate, the real national house price index, and the private debtto-GDP ratio. Real variables are obtained by deflating nominal variables by the consumer price index (CPI, all items). Output, house prices and the debt-to-GDP ratio are expressed in percentage deviation from the trend calculated using a one-sided HP filter. Inflation is the quarter-over-quarter log-difference in CPI (all items). The short-term interest rate is the three-month Treasury Bill (T-Bill) rate.

We estimate the model by least squares with a lag length of 2 over the sample period 1975Q1-2014Q4. A monetary policy shock is identified via sign restrictions as in Uhlig (2005). We impose the restriction that after a contractionary monetary policy shock that increases the short-term interest rate (normalized to a 100-basis-point response on impact), neither the output gap nor inflation increase. To capture the effects in the housing market, the response of property prices is also restricted to be non-positive. The restriction imposed on real house prices is consistent with DSGE models that incorporate a housing sector, such as Iacoviello (2005) or Iacoviello and Neri (2010) and the semi-structural model of Svensson (2013). Responses of all variables are constrained only on impact.

We remain agnostic about the behavior of the debt-to-GDP ratio by not restricting its response. For the numerator, an increase in the interest rate will likely discourage lending by increasing borrowing costs. However, a higher policy rate will also lower the inflation rate, further increasing the real cost of borrowing, on the one hand, but increasing the real value of the existing debt stock on the other. Therefore, the total effect of a monetary policy shock on real debt will depend on how monetary policy interventions transmit to both mortgage rates and inflation. For the denominator, the shock will cause output to decline. Thus, the 
response of the debt-to-GDP ratio is a priori unclear and depends on the relative size of the responses of debt and output.

In the case of sign restrictions, inference is complicated by the fact that the impulse responses are not point identified, but only set identified; i.e. impulse responses are bounded up to an interval (Moon and Schorfheide 2012). While most of the existing literature uses Bayesian methods to derive the highest posterior density intervals in these models, we conduct inference using the novel frequentist procedure outlined in Moon, Schorfheide and Granziera (2013), which is based on a Bonferroni approach. We prefer the frequentist approach, as the Bayesian approach for set-identified models is sensitive to the choice of priors even in large samples (Moon and Schorfheide 2012, Giacomini and Kitagawa 2015). Average impulse responses across countries are obtained by pooling individual country responses with weights corresponding to the country share of output.

\subsection{Impulse responses}

Figure 5 shows the impulse response functions of each variable after the unanticipated 100basis-point increase in the short-term rate. We show the 68 per cent confidence interval for the impulse responses as well as the average of the confidence set.

After a sizable, contractionary monetary policy shock, output falls below potential for about 10 quarters. Inflation also falls, but by less than output, and the response becomes insignificant after one year. The private debt-to-GDP ratio increases on impact, although the response is only slightly significantly different from zero. The ratio falls below trend in the medium and long run.

To help with the interpretation of this latter result, we also compute the impulse responses of the real private debt and nominal private debt in deviation from a one-sided HP filter trend. The responses are obtained from analogous structural VAR models in which the real or nominal debt is used in place of the private debt-to-GDP ratio. These additional exercises, shown in Figure 6, reveal that the monetary policy shock causes only a moderate reduction in nominal debt on impact. Similar to the results in Svensson (2013) and Gelain et al. (2015), the stock of nominal debt exhibits considerable inertia, as agents find it difficult to change existing contracts. Given that the fall in inflation is larger than the reduction in nominal debt, after a monetary policy shock real debt rises slightly on impact. As nominal debt further decreases and inflation quickly rebounds, real debt falls below trend from the first quarter after the shock. 
Output shrinks, so the debt-to-GDP ratio rises on impact by about 0.85 per cent (Figure 5). However, starting from the first quarter after the shock, debt decreases and the output gap becomes smaller (in absolute terms). As the decline in the debt is larger than the fall in output, a tightening of monetary policy will decrease the debt-to-GDP ratio in the medium run and long run, starting after approximately six quarters. After five years from the initial tightening, the debt-to-GDP ratio is about 14 per cent lower in percentage deviation from trend than before the tightening.

The effect of the monetary policy shock is more pronounced on house prices than it is on either real output or real debt. While house prices and output respond by roughly the same magnitude on impact, after two quarters the response of house prices is more than twice as strong as that of output. This result is consistent with other structural panel VAR studies such as Assenmacher-Wesche and Gerlach (2008). House prices dip by about 3 per cent one year after the shock and recover only in the long run.

Our results can be compared with a number of others from the literature. Using Norwegian data that run from the mid-1990s to 2013, Robstad (2014) finds that the debt-to-GDP ratio rises following a contractionary monetary policy shock. However, Laseen and Strid (2013) conduct a similar analysis using Swedish data and report a decline in the debt-toGDP ratio after a tightening. Using a pre-financial crisis sample of US data, Angeloni et al. (2015) find that both industrial production and household debt decline over all horizons considered. Although they do not provide the response of the debt-to-GDP ratio, the relative changes in the household debt and industrial production suggest that the debt-to-GDP ratio increases slightly in the short run but it falls, although only moderately, in the long run, as real activity rebounds quickly while the effect of a monetary shock on household debt is long lived. All these studies are based on single-country evidence and restrict real debt to not change on impact in response to a contractionary monetary policy shock.

Our results are more comparable with those of Goodhart and Hofmann (2008), who use a panel VAR estimated over 1970-2006 and do not restrict the contemporaneous response of debt. As in our analysis, after a 100-basis-point raise in the interest rate, real debt and the debt-to-GDP increase on impact. However, in Goodhart and Hofmann (2008), while both debt and output decline from the second quarter after the shock, the response of debt is much stronger than the response of output. This leads to a substantial decline in the debt-to-GDP ratio in the medium and long run. The response of the debt-to-GDP ratio in our paper is qualitatively consistent with the structural studies of Alpanda and Zubairy (2015.) Gelain et al. (2015), Chen and Columba (2016), and Svensson (2013). 


\subsection{Robustness analysis}

In this subsection, we present a series of robustness checks on the VAR model. The characteristics of residential mortgage markets may affect the transmission of monetary policy (Assenmacher-Wesche and Gerlach 2008, Garriga et al. 2013). In particular, the proportion of fixed versus variable mortgage rates matters for the response of house prices, residential investment and output to a monetary policy shock. We therefore investigate whether the responses of debt and debt-to-GDP differ according to the mortgage scheme by estimating the panel VAR on two subsamples of countries that are grouped according to their prevailing mortgage structure (Tsatsaronis and Zhu 2004). Panel (a) of Figure 7 shows that the effect of a monetary policy tightening on the debt-to-GDP ratio is qualitatively and quantitatively very similar across samples.

We have examined a number of alternative specifications of the model. In the benchmark specification, we prefer using the three-month rate rather than the target rate to mitigate the issues associated with the zero lower bound constraint, binding at the end of our sample. However, the short-term rate includes a risk premium that is absent in the target rate. Then, in a second experiment, we repeated our estimation with the policy rate in place of the threemonth rate. Long-term rates are relevant for debt dynamics, as they will affect mortgage subscriptions. Hence, in a third exercise, we add them to the variables in our baseline VAR

specification. The transmission of monetary policy might have been distorted during the financial crisis, so in a fourth experiment we limit our estimation sample to 2006Q4.

In all these additional exercises, shown in panel (b) of Figure 7, our impulse responses are generally well within the confidence bounds of the baseline model throughout all horizons considered.

Despite its long-standing tradition in macroeconomics, the HP filter presents some drawbacks. Specifically, it generates spurious dynamic relations and it is subject to the end of sample problem; i.e., the filter produces a trend component that is close to the observed data at the beginning and at the end of the sample. For these reasons, we have tried using data detrended by taking log-differences for output, house prices and the debt-to-GDP ratio. We find that on impact, debt-to-GDP ratio in log-differences rises by more than the debt-to-GDP gap. However, the response for log-differences quickly converges to zero as it is less persistent than the response of the gap. Log-differenced data would imply a permanent effect of monetary policy shocks on the level of the variables. Therefore, we prefer working with HP-filtered series.

As further checks on the robustness of our results, we tried different identification strate- 
gies of the monetary policy shock. First, we added a zero restriction on impact for output to the sign restrictions imposed on the other variables. While the qualitative response did not change, imposing a zero response on output dampens the impact of the monetary policy shock on the debt-to-GDP gap, as shown in panel (c) of Figure 7.

Finally, we try to identify the monetary policy shock, resorting to short-run restrictions. In a first experiment in which house prices and debt-to-GDP are ordered after the interest rate, we find qualitatively similar results to those obtained using sign restrictions for house prices, and the debt-to-GDP ratio, although the response is muted (panel (c) of Figure 7). In a further experiment in which the interest rate is ordered last and therefore debt cannot respond to monetary policy shocks on impact, we find that, differently from the signrestriction identification strategy, in the short run debt-to-GDP does not increase, while the medium and long-run responses are analogous to that generated via sign restrictions.

\section{Leverage Dynamics and Financial Stability Risks}

We have shown that a monetary policy tightening decreases the debt-to-GDP gap, at least in the medium to long run. Although the magnitude of the decrease seems moderate, to evaluate its importance we should understand how the dynamics of the ratio impact the soundness of the financial system. The recent literature finds that a rapid expansion in credit is associated with a higher likelihood of experiencing a systemic banking crisis or a financial crisis recession (Gourinchas and Obstfeld 2012; Jorda, Schularick and Taylor 2015). Baron and Xiong (2016) show that rapid credit growth may also lead to a large correction in bank equity prices.

The mechanism at work is the following: a large and rapid expansion of bank credit might drive funds to private-sector borrowers with poor credit quality, exposing banks to a higher number of defaults in case of adverse shocks. Such shocks may lead to a sharp drop in banks' equity prices. Because of the leading role played by banks in providing credit to the private sector, a sizeable correction in the bank equity index might cause a decline in the supply of credit as leverage constraints become binding. Large drops in equity prices and the consequent depletion of bank capital might then trigger a systemic banking crisis, which might require government interventions.

In this section we evaluate how reductions in leverage will translate into a less risky financial system by quantitatively assessing the linkages between deviations of debt-to-GDP from trend and the likelihood of a banking crisis. 


\subsection{Assessing the likelihoods of crises}

In order to understand the role of excessive credit as a source of financial instability, we estimate its impact on the probability of a systemic banking crisis or a large bank equity correction occurring in the near future using a panel logit regression framework. We follow Schularick and Taylor (2012) in using a cross-country panel, as the number of episodes for each country is limited and inference conducted on a single country may be misleading.

Following Gourinchas and Obstfeld (2012) and others, we construct a forward-looking dummy variable for crisis events as follows: define $f_{i, t}^{k}$ to be the dummy variable that takes the value 1 if a financial stability risk episode of type $k$ starts within the next eight quarters in country $i$, where $k=\{s b, e c\}$. Here "sb" denotes a systemic banking crisis and "ec" an equity correction. We consider a horizon of eight quarters, which is of interest to monetary policy authorities. To reflect the uncertainty in the dating of the crisis episodes, we let $f_{i, t}^{s b}$ take the value of 1 in the first year of the crisis also. Thus, our panel logit regression takes the form:

$$
\operatorname{Pr}\left(f_{i, t}^{k}=1 \mid \delta_{i}^{k}, x_{i, t}\right)=\frac{\exp \left(\delta_{i}^{k}+\beta_{k} x_{i, t}\right)}{1+\exp \left(\delta_{i}^{k}+\beta_{k} x_{i, t}\right)},
$$

where $\delta_{i}^{k}$ is the country fixed effect and $x_{i, t}$ is the set of explanatory variables. We consider two regression models, one that includes only the debt-to-GDP ratio in deviation from trend, and a second that includes all of the variables used in the VAR. By including only the debtto-GDP ratio in the first regression, we impose that the other variables affect the probability of a crisis only through their effects on leverage.

Table 2 shows the results of the panel logit model for the two types of crises and the two set of regressors. All specifications include country-specific fixed effects to allow for cross-country, time-invariant heterogeneity.

The debt-to-GDP ratio is a positive, highly significant predictor of systemic banking crises (Table 2, first column). As the other variables from the VAR are not statistically significant predictors (second column), we will use the debt-to-GDP ratio as the sole predictor in the subsequent analysis (Section 4.2).

It is important to assess the fitted value of the model to understand the adjustments to the likelihoods that result from monetary policy innovations. Panel (a) of Figure 8 shows the fitted values of the model for systemic banking crises across the countries in the sample, over the range of debt-to-GDP ratios experienced in sample. The graph shows that when the debt-to-GDP ratio is at its trend level, the estimated probability of a crisis starting sometime in the next two years ranges from approximately 1 to 12 per cent. When the ratio 
is below this value, the probabilities compress to low levels. What is more interesting is the sharp increase in the likelihood of the onset of a financial crisis when the debt-to-GDP ratio moves above trend. For example, when the debt-to-GDP ratio is 20 per cent above trend, the likelihood of a financial crisis for some countries can be quite high, at 30 per cent or higher. At larger deviations of the ratio, the likelihoods can increase to 60 per cent.

A similar exercise for the model to predict large equity market corrections can be undertaken. The coefficient on the debt-to-GDP ratio is again positive and statistically significant (Table 2, column 3). When the other variables from the VAR are added, we obtain significant coefficients on the inflation and output gap measures. However, the fitted values from the two specifications are similar, so we focus on the model containing only the debt-to-GDP ratio. It is interesting to note that the fitted values of this model display a more linear relationship between the debt-to-GDP ratio and the likelihood of an equity correction (Figure 7, panel (b)). However, we note that the estimated levels may be quite high for this model as well. For example, when the ratio is at its trend value, the likelihood of a correction ranges from approximately 5 per cent up to 35 per cent. When the ratio is 20 per cent above trend level, the likelihood may increase to 15 to 45 per cent.

The ability of the models to forecast financial crises and bank equity corrections can be assessed using the area under the receiver operating characteristic curve (AUROC). This statistic estimates the likelihood of making correct decisions (Schularick and Taylor (2012), Jorda (2014)). The area varies between 50 and 100 per cent. In the results here, the values of the AUROC statistic for models that contain only the debt-to-GDP ratio are 62.4 and 71.5 per cent, suggesting that the ratio is more successful in predicting financial crises and corrections than is a random coin toss. We note that the value of these statistics are in line with those in Schularick and Taylor (2012), in which the model to predict financial crises using the growth of private credit has an AUROC statistic of 67 per cent.

\subsection{Monetary policy and financial stability risks}

In the previous sections, we completed two separate exercises. In the first, we derived the response of the leverage of the private sector (i.e., the debt-to-GDP ratio) to an unexpected monetary policy tightening. Then, we showed that the ratio, in deviations from trend, is a significant predictor of systemic banking crises and large bank equity corrections.

We are now in a position to answer the question of how monetary policy can ultimately affect financial stability. We assess how an unanticipated monetary policy tightening affects 
the probability of a financial crisis via the debt-to-GDP ratio. The estimated impulse response of the debt-to-GDP ratio to a tightening can be calculated from the VAR model. The panel logit regression tells us how this affects the probability of a crisis. Given these two estimates, we compute the changes in the probability of a financial crisis that can be attributed to the unanticipated monetary policy shock.

The experiment is conducted as follows. We first compute the probability of a financial crisis occurring within the next two years for an initial, given deviation of the debt-to-GDP ratio from trend. This probability is obtained from the estimated panel logit model that includes only the country fixed effects and the debt-to-GDP ratio as predictors. In this exercise, for all the initial debt-to-GDP gap values considered, we set the country fixed effect parameters to their cross-country mean value. Next, given the cumulative responses of the debt-to-GDP ratio (in deviation from trend), ${ }^{8}$ we can compute the value of the debtto-GDP gap after the shock, and the corresponding probability of a financial crisis. Finally, by comparing the probability of a financial crisis before and after the shock we can assess whether the tightening has resulted in an increase or a decrease in financial stability risks.

For example, if we assume that the debt-to-GDP ratio is at trend before the shock hits, the results of the panel logit regression imply that the probability of a systemic banking crisis (for an average country) is about 6 per cent. Figure 5 tells us that after a monetary policy shock the debt-to-GDP ratio increases by 0.85 per cent, which results in an increase in the likelihood of a financial crisis to about 6.6 per cent.

This exercise can be repeated for all of the horizons considered from the panel VAR and for different initial levels of leverage. Because our panel logit model is non-linear, the effect on the probability of a crisis will depend on the initial level of the debt-to-GDP ratio. To illustrate the non-linearities of the model, we repeat our experiment for different initial levels of the ratio. Figure 9 shows the probability of a systemic banking crisis (panel (a)) or a large bank equity correction (panel (b)) occurring within the next two years following the impulse response of the debt-to-GDP ratio, assuming the debt-to-GDP ratio is at trend, or 5 and 10 per cent above trend, before the monetary policy shock occurs.

For all initial debt-to-GDP levels considered and for both types of crises, the probability of a financial crisis rises after the shock, reaching a maximum increase approximately one year from the tightening. Then, as the debt-to-GDP ratio falls, the probability decreases sharply. As the cumulative effect on the ratio eventually becomes negative, the likelihood

\footnotetext{
${ }^{8}$ In the case of sign-restricted structural VARs, the impulse response can be bounded up to an interval, rather than a point (Moon and Schorfheide 2012). We base our analysis on the mean of the identified interval.
} 
of a crisis falls below its initial value. Thus, five years after the shock, the likelihood of a financial crisis hitting the economy is considerably lower than it was before the shock. The magnitudes of the decrease in risk are quite large.

For example, if the initial debt-to-GDP ratio is 10 per cent above trend, the likelihood of a financial crisis is approximately 18 per cent (Figure 9, panel (a)). Following the monetary policy shock, the decline in the debt-to-GDP ratio causes a decline of approximately 15 per cent in the likelihood of a systemic financial crisis. For lower initial levels of the debt-to-GDP ratio, the declines are smaller. Indeed, regardless of the initial debt level, the likelihood of a crisis falls to between 0 and 5 per cent, approximately, at the end of five years. Thus, the monetary policy tightening is able to reduce large amounts of tail risk.

A similar result holds for the effect of a tightening on the likelihood of a large bank equity correction (Figure 9, panel (b)). As these corrections are more common, the initial values of the likelihoods are higher than their counterparts for full-fledged financial crises. For example, the likelihood of a large decline in bank equity values starting sometime in the next two years is approximately 31 per cent when the debt-to-GDP ratio is 10 per cent above trend. After the monetary policy shock, the likelihood declines rapidly, falling to about 24 per cent after five years. We note that declines of similar magnitudes are experienced by economies in which the initial debt-to-GDP levels are either at trend or 5 per cent above trend (Figure 9, panel (b)). However, the terminal values of the probabilities remain higher than for their systemic banking crisis counterparts. The tightening is thus able to substantially reduce the likelihood of an extreme left-tail event (i.e., a fully fledged financial crisis) while it has a much smaller effect on a more moderate episode (i.e., a large decline in bank equity).

\section{Conclusion}

We show that a tightening of monetary policy can have a positive impact on financial stability in the long run, as it is successful in reducing leverage. However, the gains are moderate and occur in the medium to long run, approximately three years after the shock. In the short run, a tightening might instead generate financial instability as it would cause further increases in the debt-to-GDP ratio and the probability of a financial crisis occurring in the near future. Then, monetary policy might not be sufficient to maintain financial stability in the short run and additional tools, such as macroprudential policies, might be needed.

Our results also point to the fact that initial conditions matter, as the higher the initial leverage, the larger is the increase in the likelihood of a crisis. It may therefore be dangerous 
to let the debt-to-GDP ratio increase substantially above trend. This in turn suggests that the current debate on the role of monetary policy in promoting financial stability might oversimplify the issue, as the benefits and costs of "leaning against the wind" depend on when the intervenetion starts.

In interpreting our results, note that our analysis is based on the average response of variables over time and across countries. However, if the cross-country heterogeneity - for example, in macroprudential regulations - is not fully captured by fixed effects, the transmission mechanisms of monetary policy may differ. Similarly, structural breaks - because of, for example, financial liberalization or changes in the mandate of the monetary authoritymight bias our responses.

Moreover, we are not conducting a welfare analysis to weight the benefits and costsimproved financial stability and deviation of real activity and inflation from target, respectivelyof policy tightening. In addition, we are unable to weight short-term losses against long-term gains regarding financial stability. Still, we provide an important analysis in the debate on the cleaning versus leaning role of central banks by answering the question of whether monetary policy could lean against the wind and highlighting the undesired short-term effects of such policies. 
Table 1: Comparisons: Systemic Banking Crises and Large Equity Corrections

\begin{tabular}{|c|c|c|c|}
\hline & \multicolumn{2}{|c|}{ Systemic Banking } & \multirow{2}{*}{$\begin{array}{c}\text { Equity Corrections } \\
\mathrm{BX}\end{array}$} \\
\hline & $\mathrm{LV}$ & $\mathrm{LV}+\mathrm{CK}$ & \\
\hline $\begin{array}{l}\text { Frequency and Duration } \\
\text { proportion of quarters in a crisis }\end{array}$ & 0.11 & 0.18 & 0.14 \\
\hline number of crisis episodes & 18 & 26 & 88 \\
\hline average number of quarters in a crisis & 16 & 19 & 4 \\
\hline \multicolumn{4}{|l|}{ Losses } \\
\hline cumulative output change (\%) & -2.9 & -1.2 & 0.5 \\
\hline excess return on bank equity (\%) & -92.8 & -66.3 & -36.1 \\
\hline \multicolumn{4}{|l|}{ Non-Crisis Average } \\
\hline cumulative output change (\%) & 2.6 & 2.7 & 2.6 \\
\hline excess return on bank equity (\%) & 7.9 & 8.9 & 11.6 \\
\hline
\end{tabular}

Note: $\overline{L V \text { refers to the Laeven and Valencia (2012) classification, } L V+C K \text { refers to an integrated data set from }}$ Laeven and Valencia (2012) and Caprio and Klingebiel (2003), BX refers to the episodes identified as in Baron and Xiong (2016). Losses are computed on the first four quarters following the start of the crisis. 
Table 2: Panel Logit Regressions

\begin{tabular}{|c|c|c|c|c|}
\hline & \multicolumn{2}{|c|}{ Systemic Banking Crises } & \multirow{2}{*}{$\begin{array}{l}\text { Bank Equity } \\
\text { (1) }\end{array}$} & \multirow{2}{*}{$\begin{array}{c}\text { Corrections } \\
(2)\end{array}$} \\
\hline & (1) & $(2)$ & & \\
\hline \multirow{2}{*}{$d e b t / g d p_{t-1}$} & $0.128^{* * *}$ & $0.128^{* * *}$ & $0.027 * *$ & $0.031^{* *}$ \\
\hline & $(0.0359)$ & $(0.0410)$ & $(0.0136)$ & $(0.0144)$ \\
\hline \multirow[t]{2}{*}{$g d p_{t-1}$} & & 0.0136 & & $0.145^{*}$ \\
\hline & & $(0.127)$ & & $(0.076)$ \\
\hline \multirow{2}{*}{$i n f_{t-1}$} & & 0.0575 & & $-0.324^{* *}$ \\
\hline & & $(0.241)$ & & $(0.127)$ \\
\hline \multirow[t]{2}{*}{$i_{t-1}$} & & 0.0493 & & -0.034 \\
\hline & & $(0.0725)$ & & $(0.0344)$ \\
\hline \multirow[t]{2}{*}{$r h p_{t-1}$} & & 0.0287 & & 0.003 \\
\hline & & $(0.0207)$ & & $(0.009)$ \\
\hline Observations & 2,324 & 2,284 & 2,455 & 2,415 \\
\hline$R^{2}$ & 0.167 & 0.223 & 0.014 & 0.064 \\
\hline$\chi^{2}$ & 12.626 & 18.312 & 4.089 & 19.313 \\
\hline$p-v a l u e$ & 0.000 & 0.003 & 0.043 & 0.002 \\
\hline Hit rate & 0.650 & 0.658 & 0.589 & 0.593 \\
\hline standard error & 0.007 & 0.007 & 0.009 & 0.016 \\
\hline$Q P S$ & 0.163 & 0.153 & 0.357 & 0.344 \\
\hline standard error & 0.015 & 0.016 & 0.002 & 0.017 \\
\hline$A U R O C$ & 0.715 & 0.757 & 0.624 & 0.678 \\
\hline standard error & 0.018 & 0.017 & 0.012 & 0.012 \\
\hline
\end{tabular}

Note: Estimates of a panel logit with country fixed effects. The dependent variable is the occurrence of a crisis between horizon $t+1$ and horizon $t+8$ quarters. "Systemic banking crises" refers to the integrated LV $+\mathrm{CK}$ data set, while "bank equity corrections" is defined similarly to Baron and Xiong (2016). Debt-to-GDP ratio is expressed in percentage deviation from an HP-filtered trend. Significance levels at 10, 5, 1 per cent are denoted as *, ** and ***, respectively. $R^{2}$ refers to the pseudo R-squared. Robust standard errors are obtained using the multiway clustering (country and time) of Cameron et al. (2011). 
Figure 1: Private Debt-to-GDP Ratio, 1975Q1-2014Q4

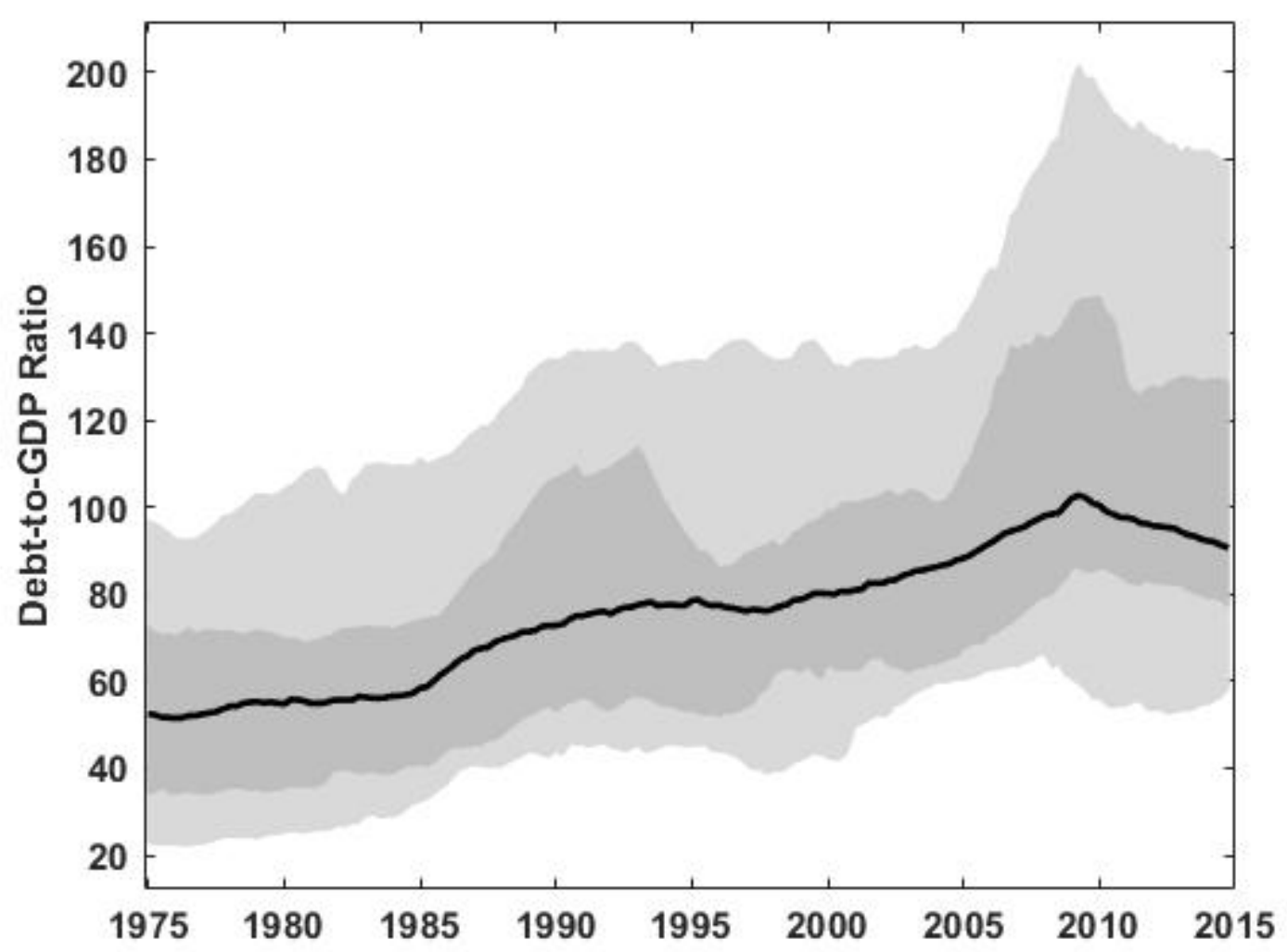

Note: Private debt-to-GDP ratio for 18 advanced economies over the sample 1975Q1-2014Q4. The black line shows the weighted average across countries, where countries are weighted by their share of output. The light grey shaded area delimits the range of values of the individual country ratio; the dark shaded area, the $20 \%$ and $80 \%$ percentiles. 
Figure 2: Financial Cycles, 1975Q1-2014Q4

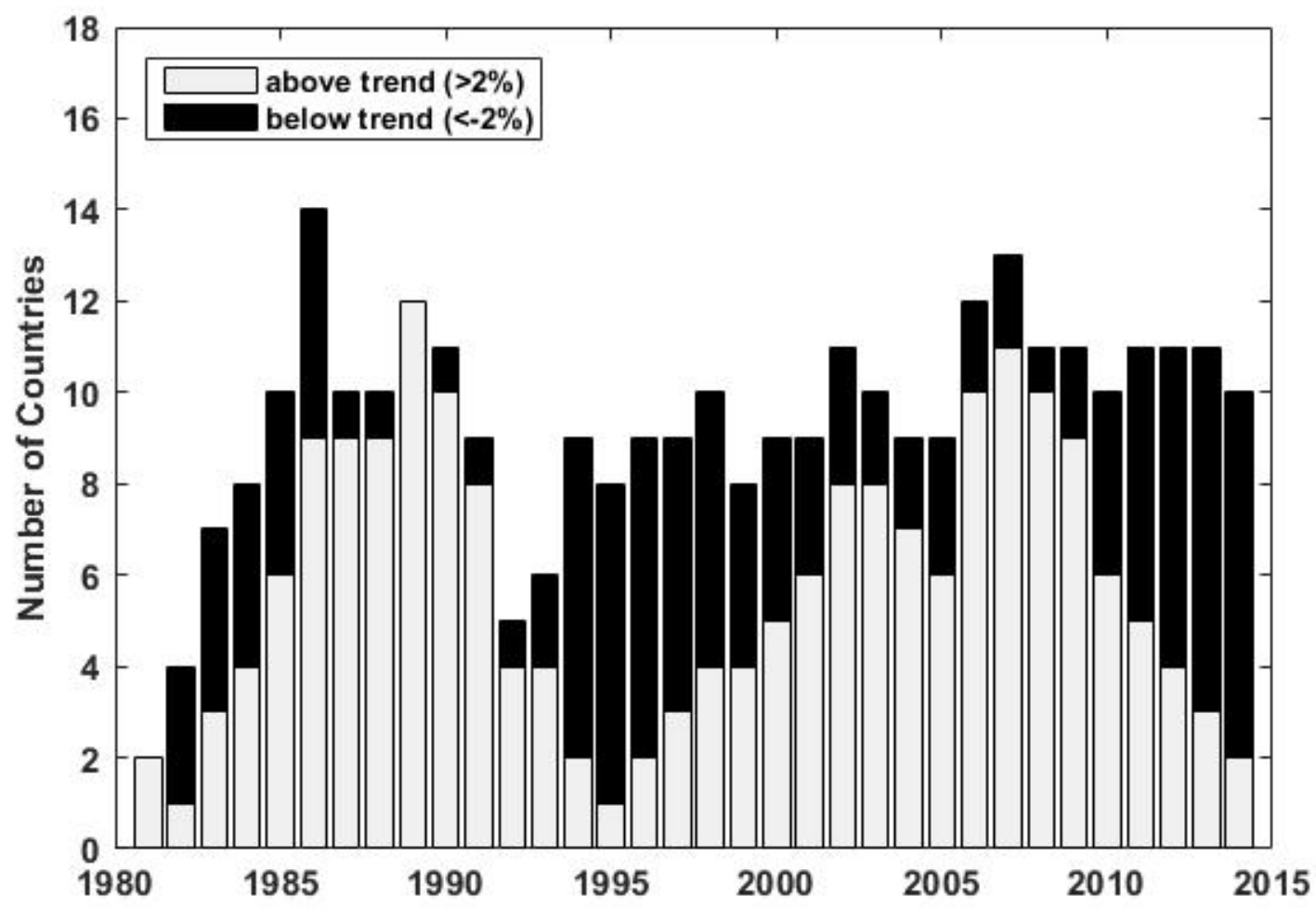

Note: Number of countries with debt-to-GDP ratio on average at least 2 per cent above (below) trend in grey (black) in a given year. The trend is constructed using a one-sided HP filter with smoothing parameter of 400,000. 
Figure 3: Frequency of Systemic Banking Crises and Bank Equity Corrections, 1975-2011

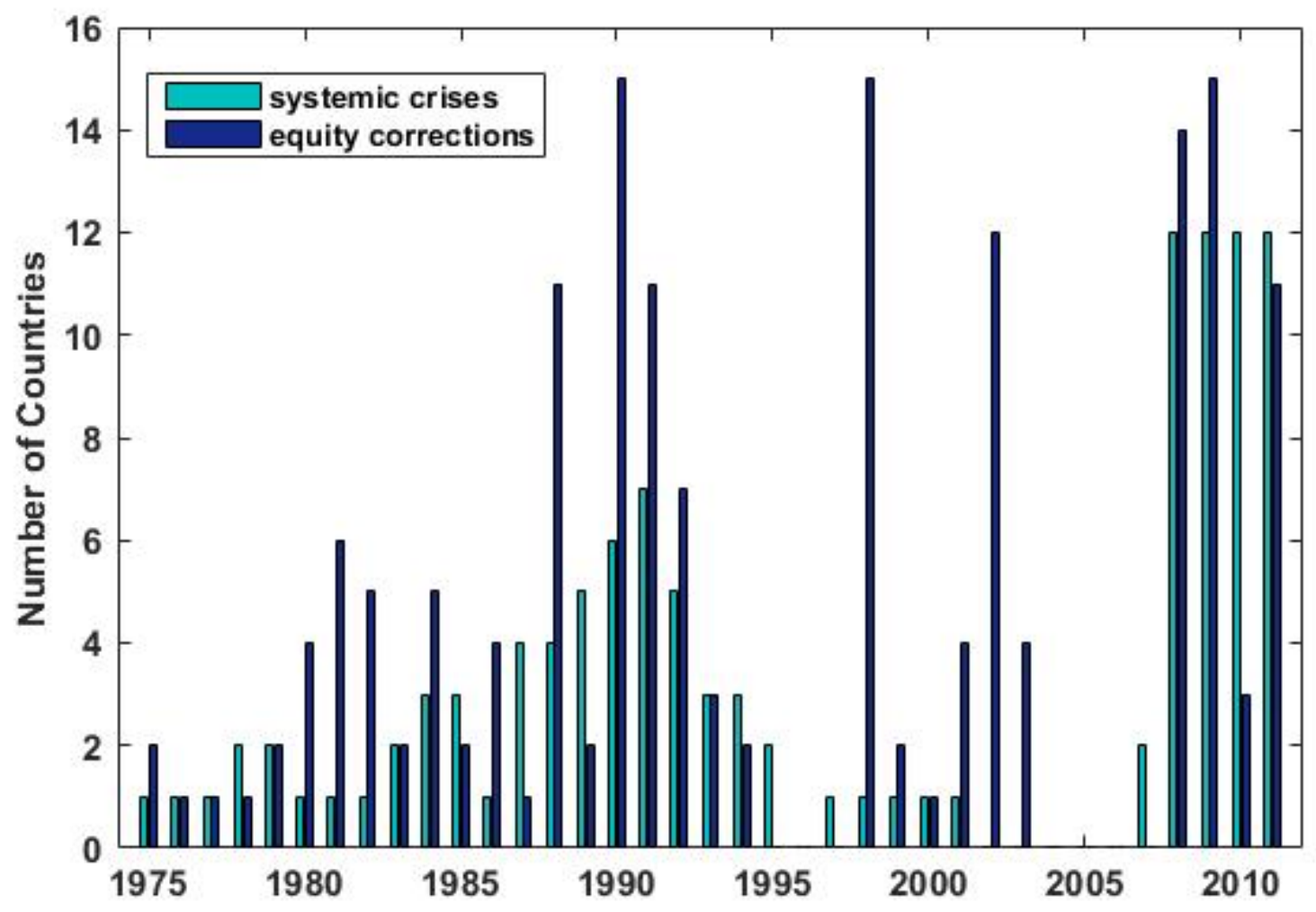

Note: Number of countries in a systemic banking crisis or large bank equity correction in a given year. A country is counted as having experienced a crisis episode in a given year if it has experienced a crisis episode in at least one quarter of that year. The classification of systemic banking crisis is based on Caprio and Klingebiel (2003) and Laeven and Valencia (2012). We follow Baron and Xiong (2016) for large bank equity corrections. 
Figure 4: Event Study

\section{(a) Systemic Banking Crises}
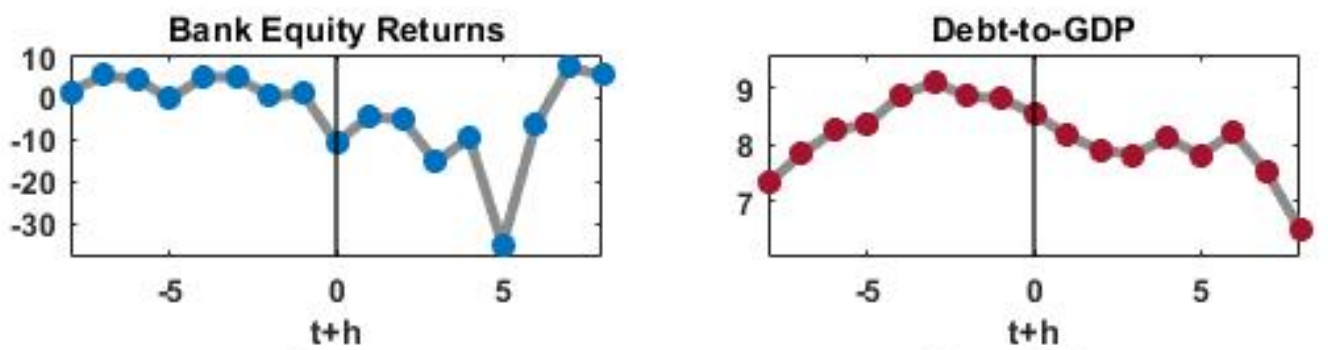

Output

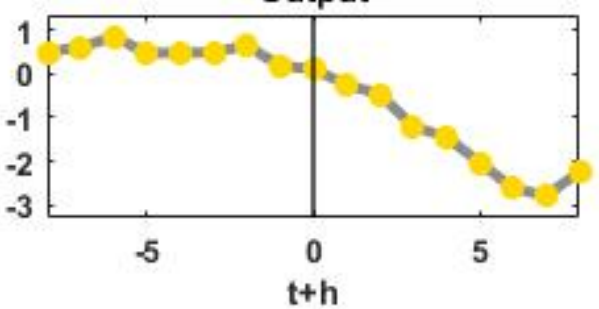

House Prices

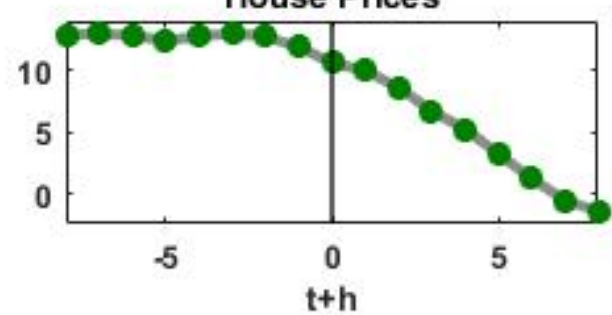

(b) Large Bank Equity Corrections
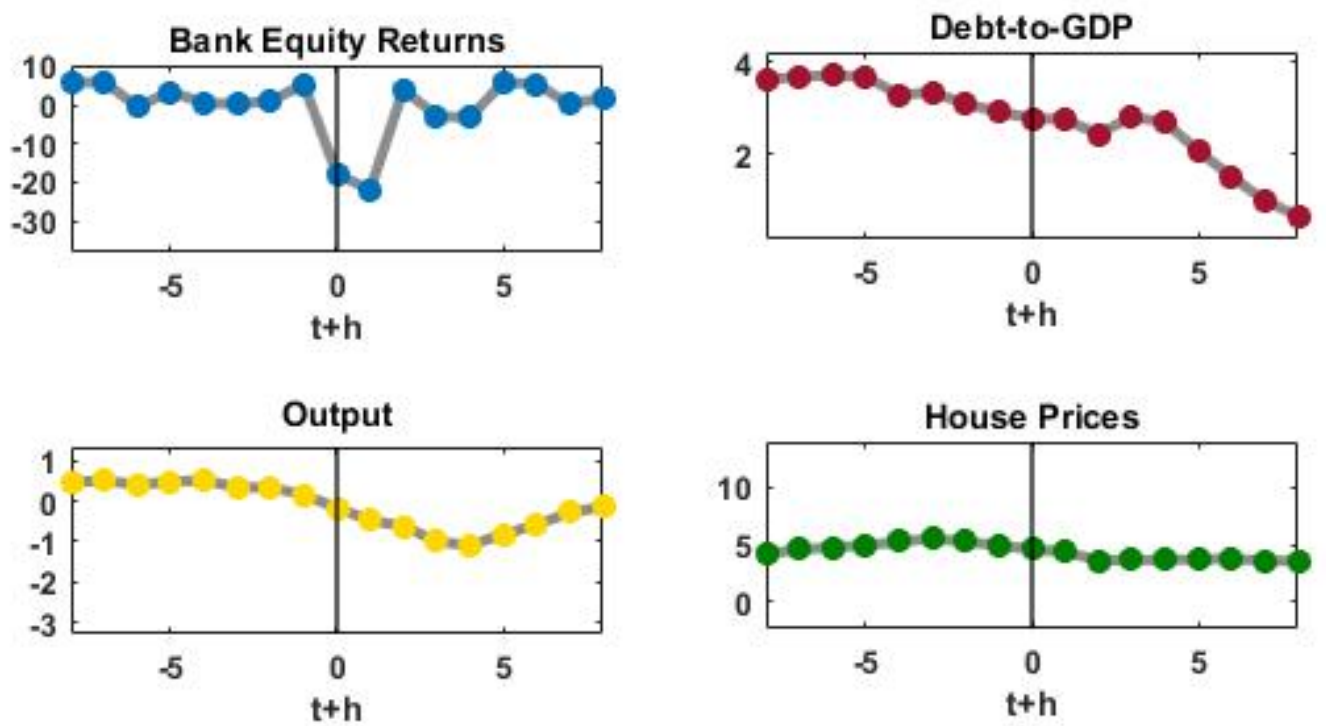

Note: Average of selected variables around crisis episodes: (a) systemic banking crises; (b) large bank equity corrections. 
Figure 5: Responses to a Monetary Policy Shock
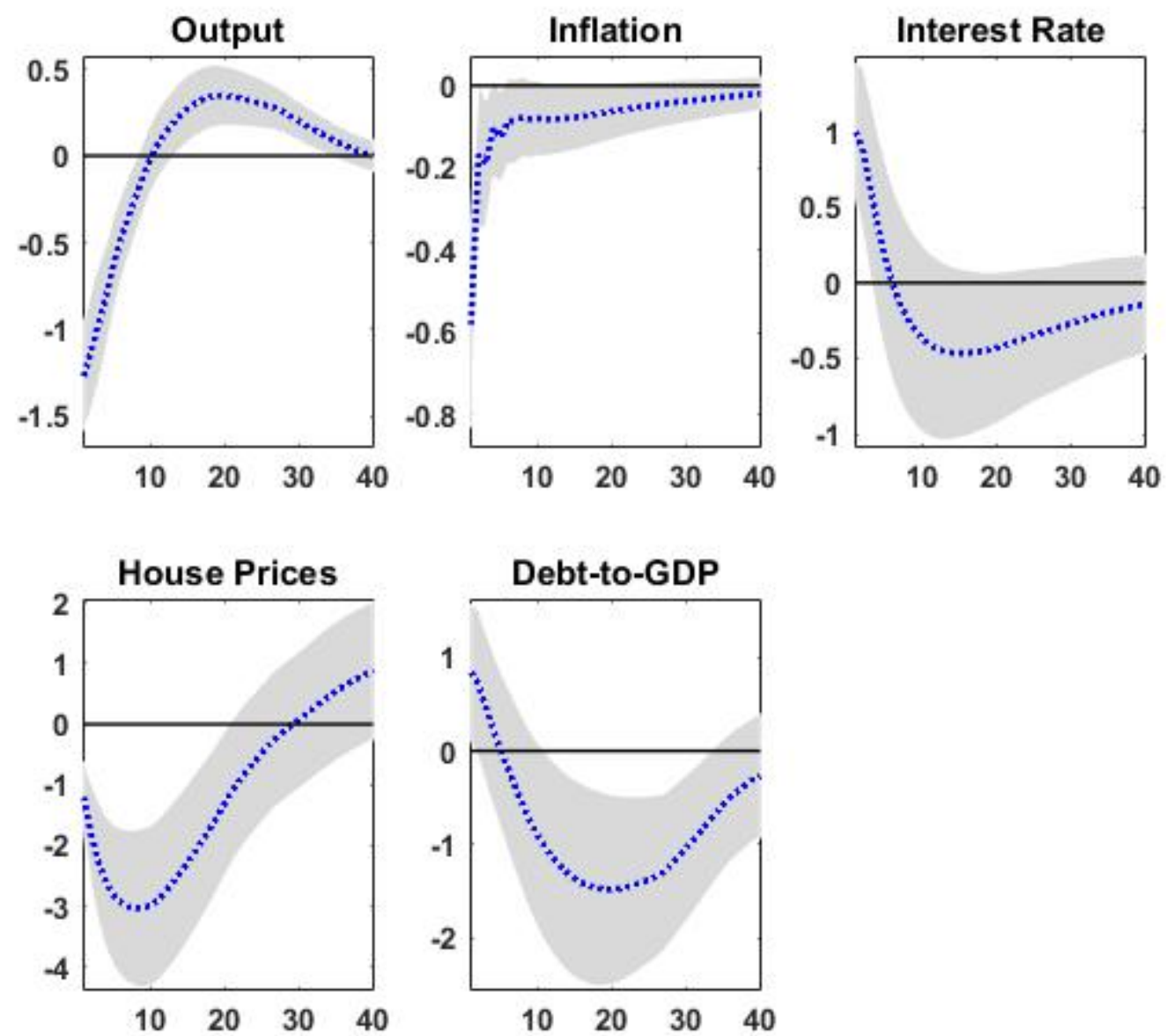

Note: Impulse response functions after a 100-basis-point contractionary monetary policy shock. Dashed lines indicate the average response; shaded area indicates $68 \%$ confidence set obtained with the frequentist procedure in Moon et al. (2013). 
Figure 6: Responses to a Monetary Policy Shock: Nominal Debt and Real Debt

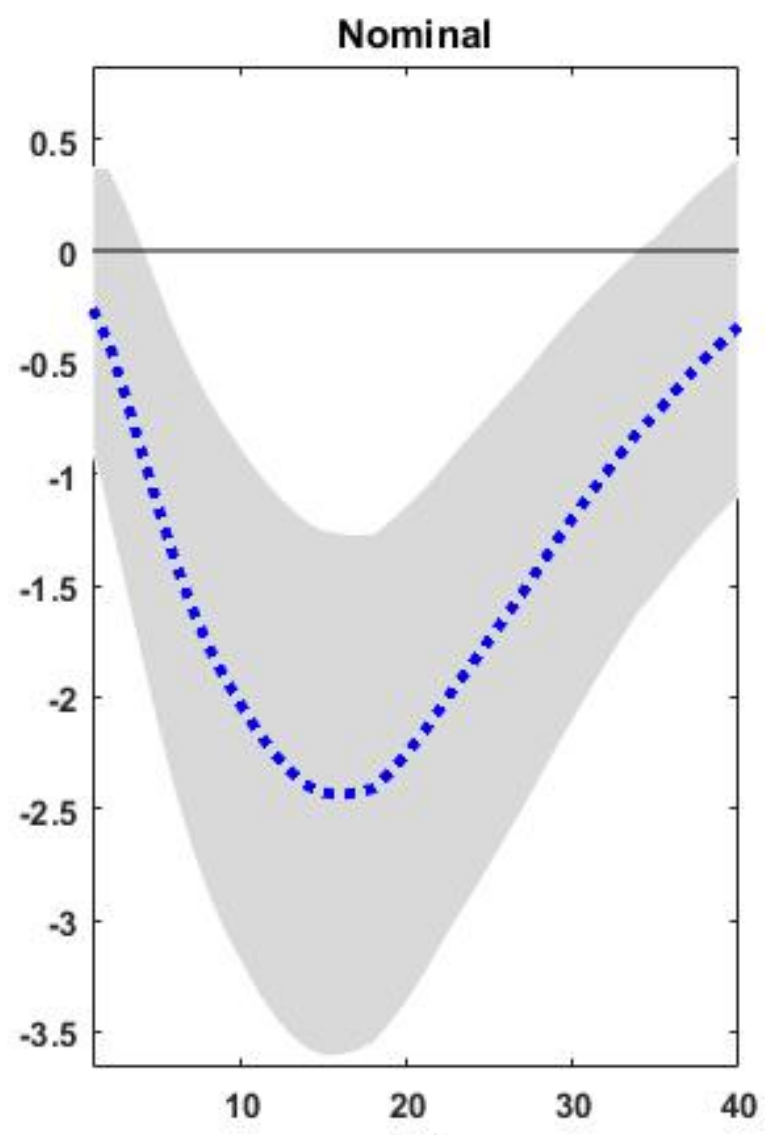

(a)

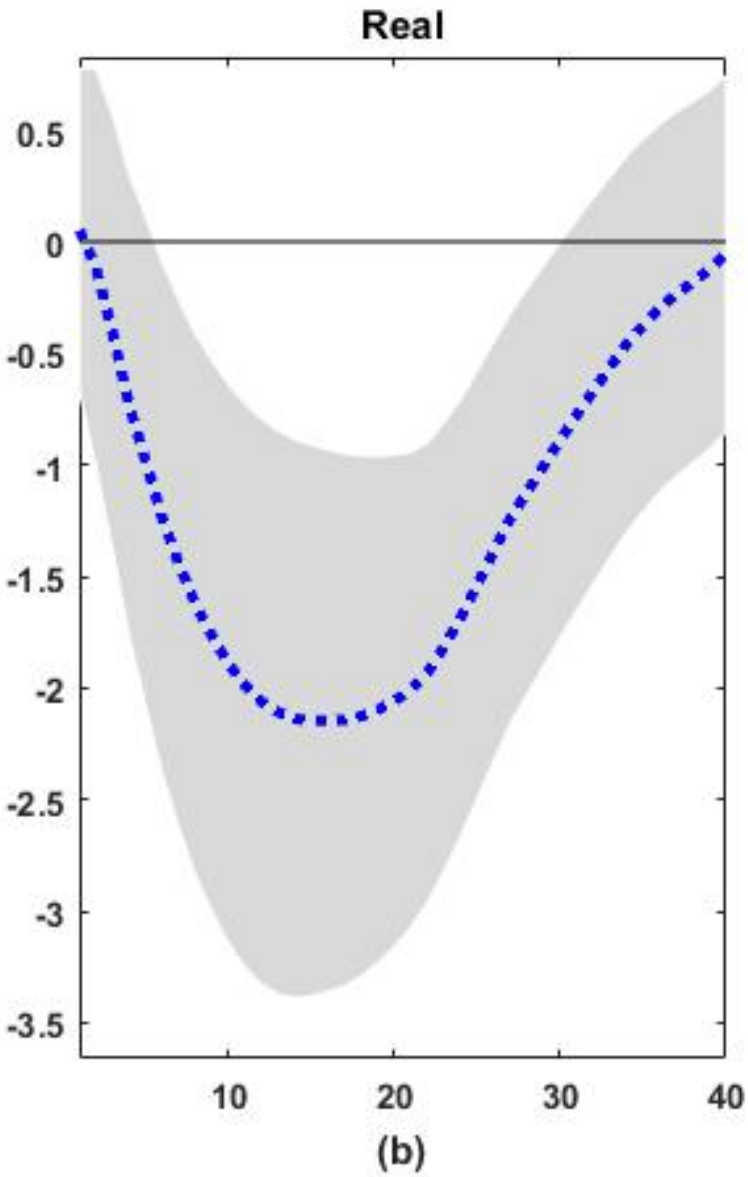

(b)

Note: Impulse response functions of nominal debt (panel (a)) and real debt (panel (b)) after a 100-basis-point contractionary monetary policy shock. Dashed lines indicate the average response; shaded area indicates $68 \%$ confidence sets. 
Figure 7: IRF: Robustness Analysis

(a)

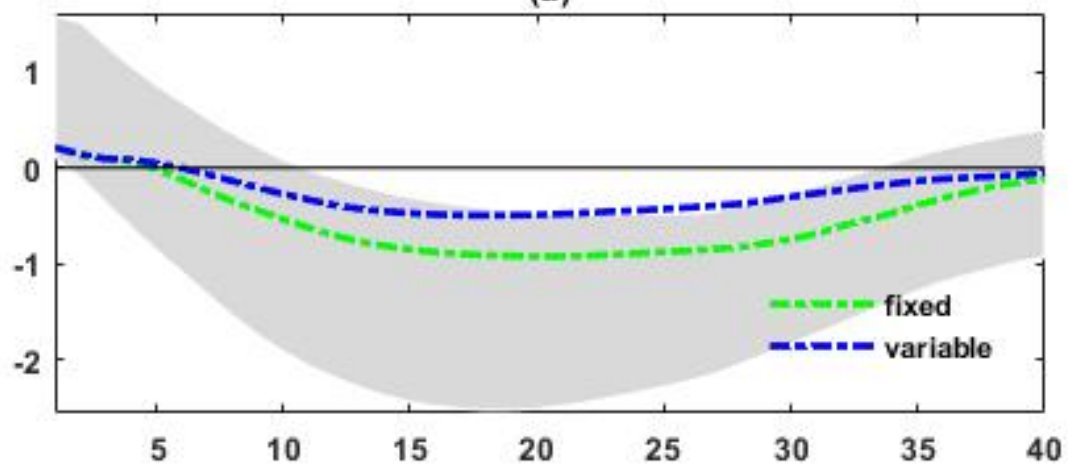

(b)

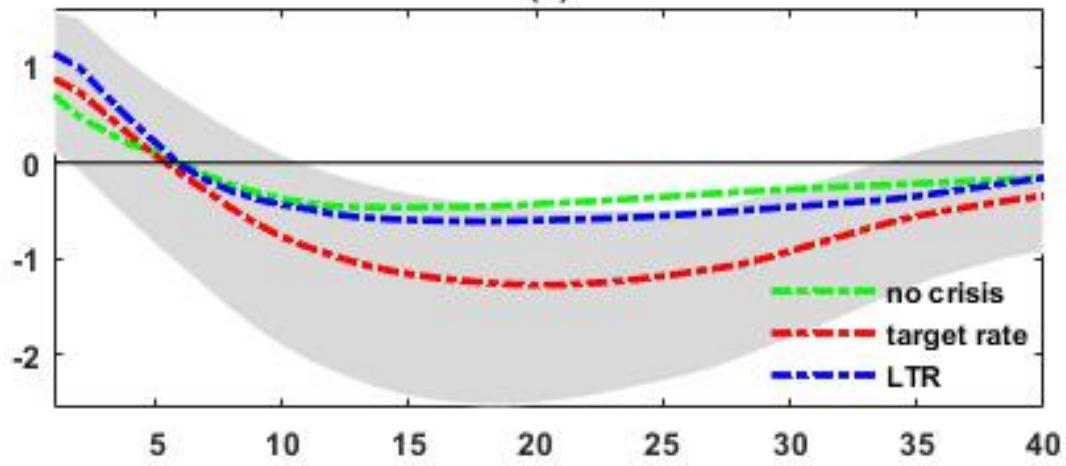

(c)

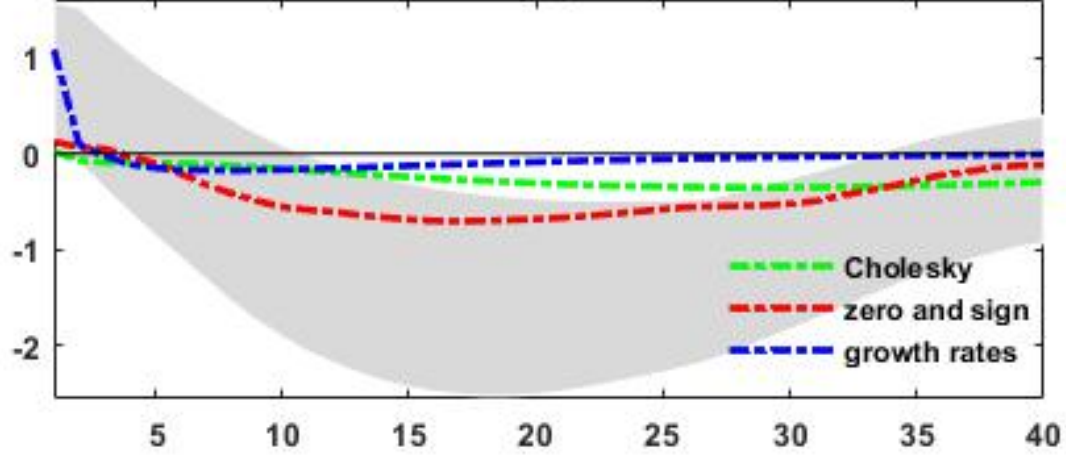

Note: Impulse response functions of debt-to-GDP in deviation from trend after a 100-basis-point contractionary monetary policy shock. Dashed line indicates the average responses from different robustness experiment; shaded area indicates the $68 \%$ confidence set for the impulse responses obtained from the baseline VAR. 
Figure 8: Financial Crisis Predicted Probabilities

(a) Systemic Banking Crises

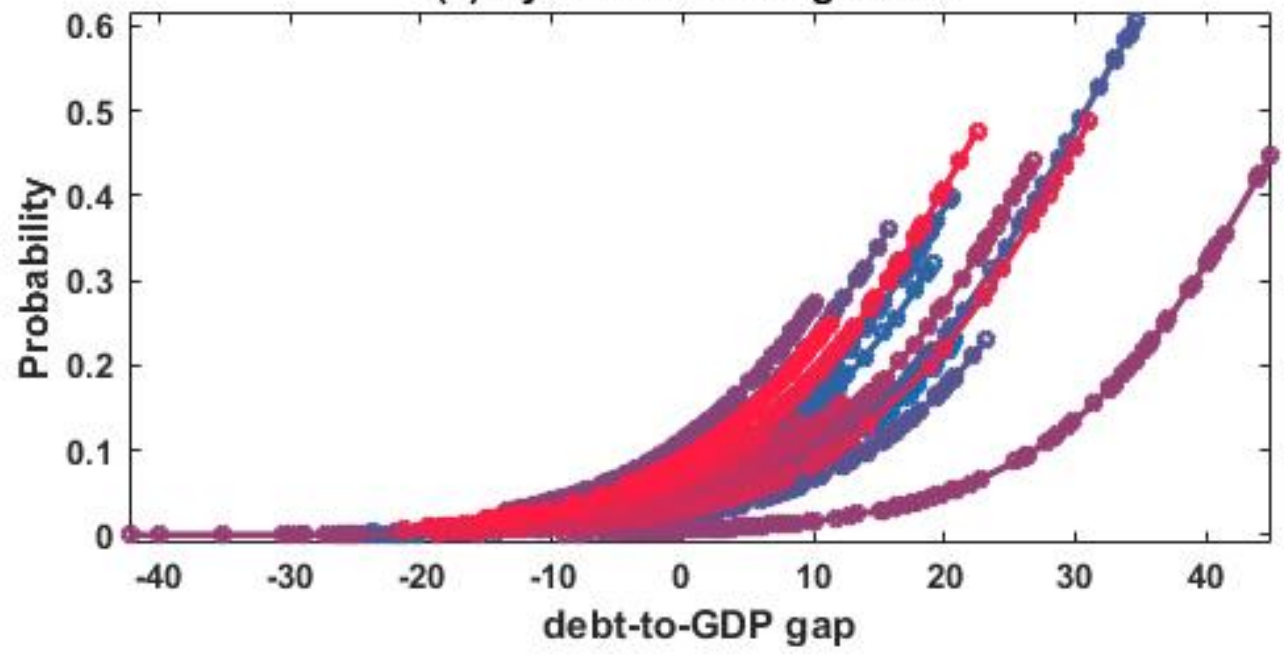

(b) Large Bank Equity Corrections

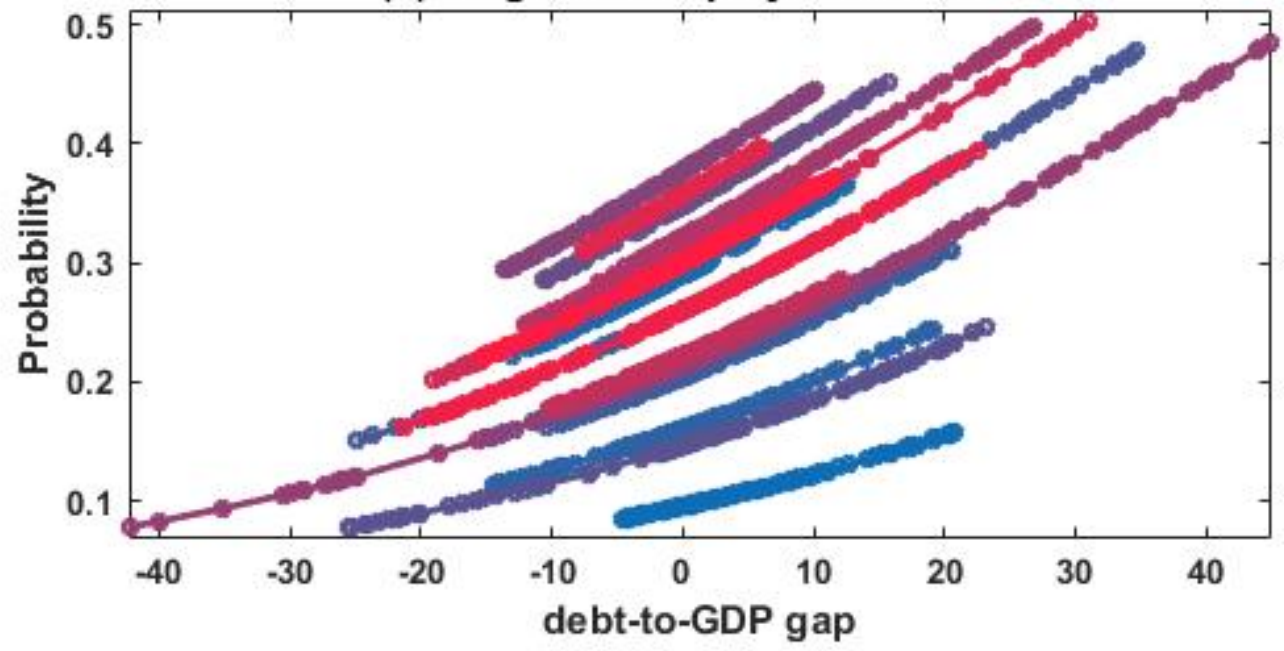

Note: Probabilities are obtained from a panel logit regression in which the dependent variable is a dummy taking the value 1 if a systemic banking crisis (a) or a large bank equity correction (b) occurs within the next eight quarters. The logit models, described in detail in Section 4, include only the country fixed effect and the lagged debt-to-GDP ratio. 
Figure 9: Effect of a Monetary Policy Shock on Crisis Probabilities

(a) Systemic Banking Crisis

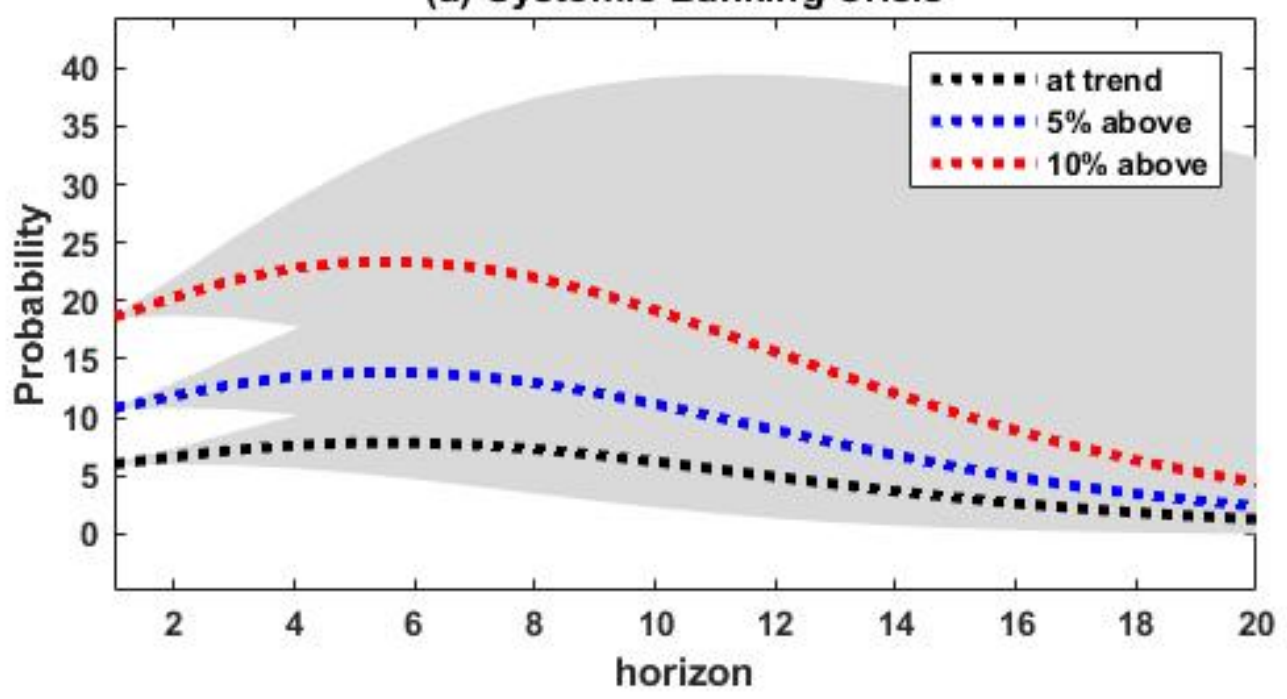

(b) Large Bank Equity Correction

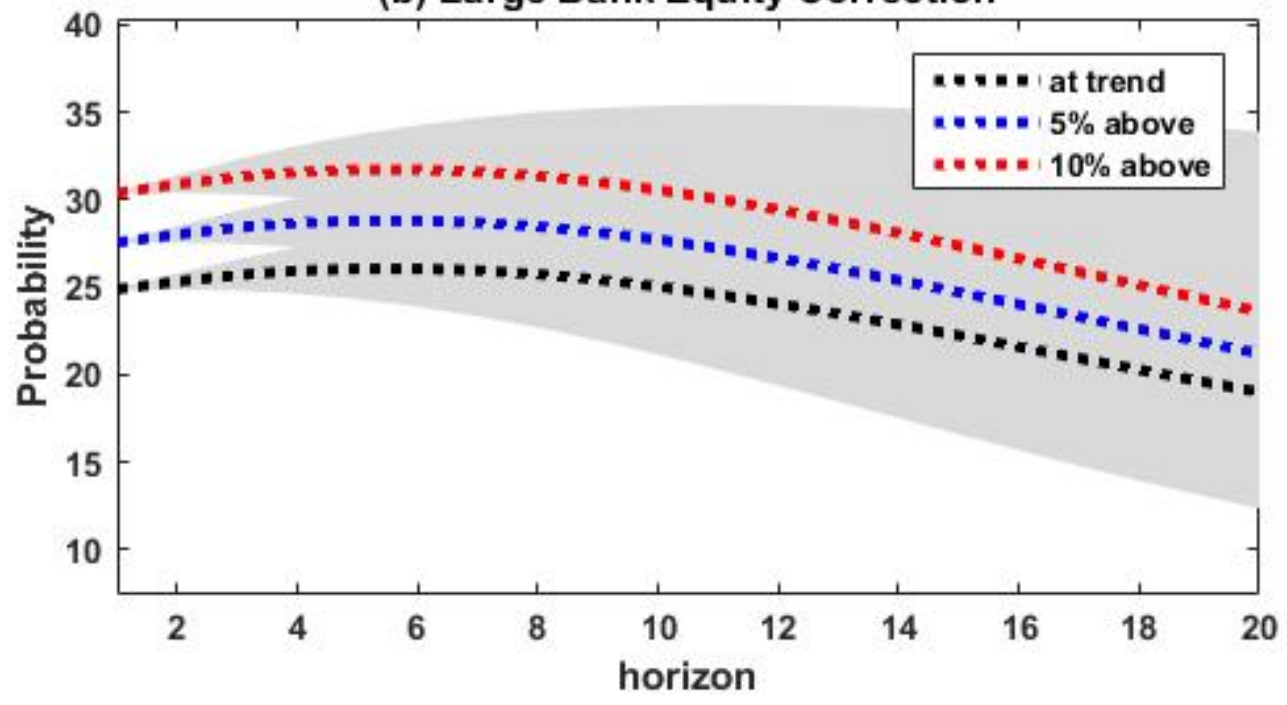

Note: Probability of a crisis occurring within the next two years given the responses of the debtto-GDP ratio, following a 100-basis-point monetary policy shock. Probability of a financial crisis is calculated assuming that before the monetary policy shock hits, the debt-to-GDP is (i) at trend, (ii) 5 per cent, (iii) 10 per cent above trend. Shaded areas delimit the $68 \%$ confidence set. 


\section{References}

[1] Adrian, T., E. Moench, and H.S. Shin (2013), "Leverage asset pricing," Federal Reserve Bank of New York Staff Reports 625.

[2] Aikman, D., M. T. Kiley, S. J. Lee, M. G. Palumbo, and M. N. Warusawitharana (2015), "Mapping Heat in the U.S. Financial System," Finance and Economics Discussion Series 2015-059. Washington: Board of Governors of the Federal Reserve System.

[3] Aikman, D., A. Lehnert, N. Liang, and M. Modungo. (2016). "Financial Vulnerabilitites, Macroeconomic Dynamics, and Monetary Policy," Finance and Economics Discussion Series 2016-055. Washington: Board of Governors of the Federal Reserve System.

[4] Ajello, A., T. Laubach, D. Lopez-Salido, and T. Nakata (2016), "Financial Stability and Optimal Interest-Rate Policy," Finance and Economics Discussion Series 2016-067. Washington: Board of Governors of the Federal Reserve System.

[5] Allen, F. and D. Gale (2000), "Bubbles and Crises," Economic Journal 110, 236-255.

[6] Alpanda S. and S. Zubairy (2014), "Addressing Household Indebtedness: Monetary, Fiscal or Macroprudential Policy?" Bank of Canada Staff Working Paper 2014-58.

[7] Alpanda, S. and A. Ueberfeldt (2016), "Should Monetary Policy Lean Against Housing Market Booms?" Bank of Canada Staff Working Paper 2016-19.

[8] Angeloni, I., E. Faia and M. Lo Duca (2015), "Monetary Policy and Risk Taking," Journal of Economic Dynamics and Control 52 285-307.

[9] Assenmaker-Wesche K. and S. Gerlach (2008), "Financial Structure and the Impact of Monetary Policy on Asset Prices," Swiss National Bank Working Paper 2008-16.

[10] Babecký, J., T. Havranek, J. Mateju, M. Rusnák, K. Smidkova, and B. Vasicek (2012), "Banking, Debt and Currency Crises: Early Warning Indicators for Developed Countries," European Central Bank Working Paper 1485.

[11] Barberis N. (2012), "Psychology and the financial crisis of 2007-2008," in Financial Innovation and Crisis, M. Haliassos ed., Massachusetts Institute of Technology Press.

[12] Baron M. and W. Xiong (2016), "Credit Expansions and Neglected Crash Risks," Quarterly Journal of Economics, forthcoming. 
[13] Bebchuk, L. A., A. Cohen, and H. Spamann (2010), "The Wages of Failure: Executive Compensation at Bear Stearns and Lehman 2000-2008," Yale Journal on Regulation 27, $257-282$.

[14] Borio, C. (2014), "Monetary Policy and Financial Stability: What Role in Prevention and Recovery?" Bank for International Settlements Working Paper 440.

[15] Bover, O., J. M. Casado, S. Costa, P. Du Caju, Y. McCarthy, E. Sierminska, P. Tzamourani, E. Villanueva, and T. Zavadil (2016), "The Distribution of Debt Across Euro-Area Countries: The Role of Individual Characteristics, Institutions and Credit Conditions," International Journal of Central Banking 12, 71-128.

[16] Cameron, A. C., J. B. Gelbach and D. L. Miller (2011), "Robust Inference with Multiway Clustering," Journal of Business and Economic Statistics 29, 238-249.

[17] Caprio, G., D. Klingebiel, (2003), "Episodes of systemic and borderline financial crises," World Bank mimeo.

[18] Chen J. and F. Columba (2016), "Macroprudential and Monetary Policy Interactions in a DSGE Model for Sweden," International Monetary Fund Working Paper 16/74.

[19] Chen S., M. Kim, M. Otte, K. Wiseman and A. Zdzienicka (2015), "Private Sector Deleveraging and Growth Following Busts," International Monetary Fund Working Paper $15 / 35$.

[20] Danielsson, J., H.S. Shin, and J.P. Zigrand (2012), "Procyclical Leverage and Endogenous Risk," National Bureau of Economic Research Working Paper 12054.

[21] Drehmann, M. (2013), "Total Credit as an Early Warning Indicator for Systemic Banking Crises," Bank for International Settlements Quarterly Review.

[22] Garriga, C., Kydland F.E. and R. Sustek (2013), "Mortgages and Monetary Policy," St. Louis Federal Reserve Working Paper 2013-037.

[23] Gelain, P., K.J. Lansing and G. J. Natvik (2015), "Leaning Against the Credit Cycle," Norges Bank Working Paper 04/2015.

[24] Gennaioli N., A. Shleifer and R. Vishny (2012), "Neglected risks, financial innovation, and financial fragility," Journal of Financial Economics 104, 452-468. 
[25] Gennaioli N., A. Shleifer and R. Vishny (2013), "A model of shadow banking," Journal of Finance 68, 1331-1363.

[26] Gerdrup, K.R., F. Hansen, T. Krogh and J. Maih. 2016. "Leaning against the wind when credit bites back," Norges Bank Working Paper 9/2016.

[27] Giacomini, R. and T. Kitagawa (2015), "Robust inference about partially identified SVARs," mimeo.

[28] Goodhart C. and B. Hofmann (2008), "House Prices, Money, Credit and the Macroeconomy," Oxford Review of Economic Policy 24, 180-205.

[29] Gourinchas, P.O. and M. Obstfeld (2012), "Stories of the Twentieth Century for the Twenty-First," American Economic Journal: Macroeconomics 4, 226-65.

[30] Greenspan, A. (2002), "Opening Remarks," in Rethinking Stabilization Policy, Federal Reserve Bank of Kansas City Symposium, Jackson Hole.

[31] Iacoviello, M. (2005), "House Prices, Borrowing Constraints, and Monetary Policy in the Business Cycle," American Economic Review 95, 739-764.

[32] Iacoviello, M. and S. Neri (2010) "Housing Market Spillovers: Evidence from an Estimated DSGE Model," American Economic Journal: Macroeconomics 2, 125-64.

[33] Jorda, O., M. Schularick and A. M. Taylor (2015), "Betting the house," Journal of International Economics 96, S2-S18.

[34] Jorda, O., M. Schularick and A. M. Taylor (2015a), "Leveraged Bubbles," Journal of Monetary Economics 76, S1-S20.

[35] Jorda, O., M. Schularick and A. M. Taylor (2015b), "Sovereign versus Banks, Credit, Crises, and Consequences," Journal of the European Economic Association 14, 45-79.

[36] Laeven, L. and F. Valencia (2012), "Systemic Banking Crises Database: An Update," International Monetary Fund Working Paper 12/163.

[37] Laseen, S. and I. Strid (2013), "Debt Dynamics and Monetary Policy: A Note," Sveriges Riksbank Working Paper 283. 
[38] Mishkin, F. S. (2011), "How Should Central Banks Respond to Asset-Price Bubbles? The 'Lean' versus 'Clean' Debate After the GFC," Reserve Bank of Australia Bulletin $0611-8$.

[39] Moon H. R. and F. Schorfheide (2012), "Bayesian and Frequentist Inference in Partially Identified Models," Econometrica 80, 755-782.

[40] Moon, H.R., F. Schorfheide, and E. Granziera (2013), "Inference for VARs Identified with Sign Restrictions," National Bureau of Economic Research Working Paper 17140.

[41] Pesaran, H. M. and R. Smith (1995), "Estimating Long-Run Relationships from Dynamic Heterogeneous Panels," Journal of Econometrics 68, 79-113.

[42] Reinhart, C. and K. Rogoff (2009), This Time Is Different: Eight Centuries of Financial Folly, Princeton University Press.

[43] Robstad O. (2014), "House Prices, Credit and the Effect of Monetary Policy in Norway: Evidence from Structural VAR Models," Norges Bank Working Paper 05-2014.

[44] Schularick, M. and A. M. Taylor (2012), "Credit Booms Gone Bust: Monetary Policy, Leverage Cycles, and Financial Crises, 1870-2008," American Economic Review 102, 1029-1061.

[45] Smets, F. (2014), "Financial Stability and Monetary Policy, How Closely Interlinked?" International Journal of Central Banking 10, 264-300.

[46] Svensson, L. E. O. (2013), "'Leaning against the wind' Leads to a Higher (Not Lower) Household Debt-to-GDP Ratio," Working Paper, www.larseosvensson.net.

[47] Svensson, L. E. O. (2014), "Inflation Targeting and 'Leaning Against the Wind'," International Journal of Central Banking 10, 103-114.

[48] Svensson, L.E.O. (2016), "Cost-Benefit Analysis of Leaning Against the Wind: Are Costs Larger also with Less Effective Macroprudential Policy?" National Bureau of Economic Research Working Paper 21902.

[49] Taylor, J. B. (2007), "Housing and Monetary Policy," National Bureau of Economic Research Working Paper 13682. 
[50] Taylor, J. B. (2010), "Getting Back on Track: Macroeconomic Policy Lessons from the Financial Crisis," Federal Reserve Bank of St. Louis Review.

[51] Tsatsaronis, K. and H. Zhu (2004), "What drives housing price dynamics: cross-country evidence," Bank for International Settlements Quarterly Review, March.

[52] Uhlig, H. (2005), "What are the effects of monetary policy? Results from an agnostic identification procedure," Journal of Monetary Economics 52, 381-419. 